\title{
Water Quality and Bacterial Load of Water and Tilapia Organs from Edku Lake
}

\author{
Alam Eldeen Farouk \\ Department of Limnology, Central Laboratory for Aquaculture Research, Abbassa, \\ Abou-Hammad, Sharkia, Egypt \\ *Corresponding Author: alameldeenfarouk84@yahoo.com \\ Received: March 9, 2018; Accepted: March 29, 2018 Vol.8 (2):29-56
}

\begin{abstract}
Lakes are very important part of the aquatic ecosystem in Egypt. Edku Lake is one of the northern coastal lakes in Egypt which is the third largest wetland area in it. Edku Lake receives huge amounts of drainage water from four main drains, namely, Edku, El Bousily, El Khairy and Bersik which effect on its ecosystem. This study was carried out four seasons of 2017 where twenty-four surface water samples and fish samples were collected from sex stations in the lake. The results of water quality indicated that temperature, $\mathrm{pH}$, dissolved oxygen and phosphorus were indicated in suitable range at all study stations. While, ammonia and nitrite were indicated in stress range for fish, but nitrate results were lied as desirable results. Results of lake water bacterial load (TC\& CF) are exceed the permissible values mentioned by EC, 1998 and Ministry of Health, Egypt, 1996. Also, the bacterial loads (Total bacterial count, TC\& Coliform group, CF) found in this study for Nile tilapia organs (skin \& muscle) was beyond the standard value (FAO, 1979 and ICMSF, 1982), which indicate their unacceptability as food from public health point of view which may be cause human health risk due to consumption of tilapia collected.
\end{abstract}

Keywords: Edku lake, Water quality, Bacterial load.

\section{INTRODUCTION}

Lakes are one of the important water resources used for fisheries (Ramakrishnaiah et al., 2009). In Egypt, Lakes are very important part of the aquatic ecosystem, which represent about $15 \%$ of the total commercial fishing areas (Abdel-Hamid, 2017). Lake pollution is one of the serious environment problems in recent years with socio-economic development and pollutants discharge increase from industry, agriculture and domesticity. Vast number of lakes have suffered varying degrees of pollution across the world, and to monitor lake water quality, physical and chemical proxies have been commonly used 
(Ouyang et al., 2016). Basic physical and chemical parameters are included, which determine the characteristics of an aquatic system (Trikoilidou1 et al., 2017). Water is one of the most essential constituents of the human environment. The resource generates development in socio-economic issues crucial to the society in general and more specifically for industries, agricultural activities and for the public use. Water quality refers to the physical, chemical and biological characteristics of water in relation to the existence of life and especially human activity.

Microbial indicators of fecal contamination are used as an indicator of water quality, since feces may contain pathogenic organisms that have the potential to negatively impact human health. Currently, there is no routine governmental reporting of microbial indicators in one of the most valuable sources of freshwater in Saskatchewan (North et al., 2014).

Fishes are considered as one of the most significant bio-monitors in an aquatic system for the estimation of water pollution concentrations (Begum et al., 2005). Fish take a large number of bacteria into their gut from water, sediment and food (Sugita et al., 1988). Thus, by determining the bacterial contents of the water samples in grow-out ponds, the bacterial level in fish can be predicted. The latter affects the quality and storage life of the fishery products. The quality of fish refers to the degree of contamination with coliform bacteria, and it is well known that freshwater fish and their aquatic environment can harbor human pathogenic bacteria, particularly members of the coliform group (Leung et al., 1992; Pullela et al.,1998; Ramos and Lyon, 2000). In a previous study it has been demonstrated that the bacterial flora in fish reflects the aquatic environments (Shewan and Hopps, 1967).

Mandal et al. (2009) indicated that fishes are very much susceptible to contamination with different bacteria because of their highly perishable protein content in their body. Coliforms are not the normal flora of bacteria in fish. Due to deposition of human excreta in pond, water is contaminated and when this contaminated water is ingested by the fish, they become contaminated. Bacteria often occur in parts of fish such as scales, gills, gut and alimentary tract. The bacteria present on the body or internal organs of fish indicate the extent of pollution of aquatic ecosystems (Ibemenuga and Okeke, 2014).

So that, the aim of this study evaluates water quality of the lake and its effect on bacterial load (TC and CF) in water and tilapia organs (skin and muscle) of the lake.

\section{MATERIAL AND METHODS}

\section{Study area}

Edku Lake is one of the northern coastal lakes in Egypt, located at the western part of the Delta Nile (Khalil et al., 2008). It is the third largest wetland area in the northern delta. It supports a fishery of moderate importance. It is also of moderate importance for both wintering and breeding water birds (Bird Life 
International, 2008). Edku Lake is situated approximately $30 \mathrm{~km}$ east of Alexandria between Long. 30 $0^{\circ} 30^{\prime \prime}$ and $30^{\circ} 23^{\prime} 0.0^{\prime \prime} \mathrm{E}$ and Lat. $31^{\circ} 10^{\prime} 30^{\prime \prime}$ and $31^{\circ} \mathrm{N}$ (Fig., 1). Its area has decreased from $28.5^{\times} 10^{3}$ to about $12^{\times} 10^{3}$ Feddans as a result of agricultural reclamation. The depth of the lake fluctuates between 60 and $150 \mathrm{~cm}$ with an average of about one meter (Saad, 2003). Satellite images from 2007 indicate that the total surface area of the lagoon is about $62.5 \mathrm{~km}^{2}, 22$ $\mathrm{km}^{2}$ of which is open water; the remaining area $\left(42.7 \mathrm{~km}^{2}\right)$ is covered by aquatic vegetation, islands and islets. According to these estimates, the open water area thus represents only $35 \%$ of the total surface area of the lake (Moufaddal et al., 2008).

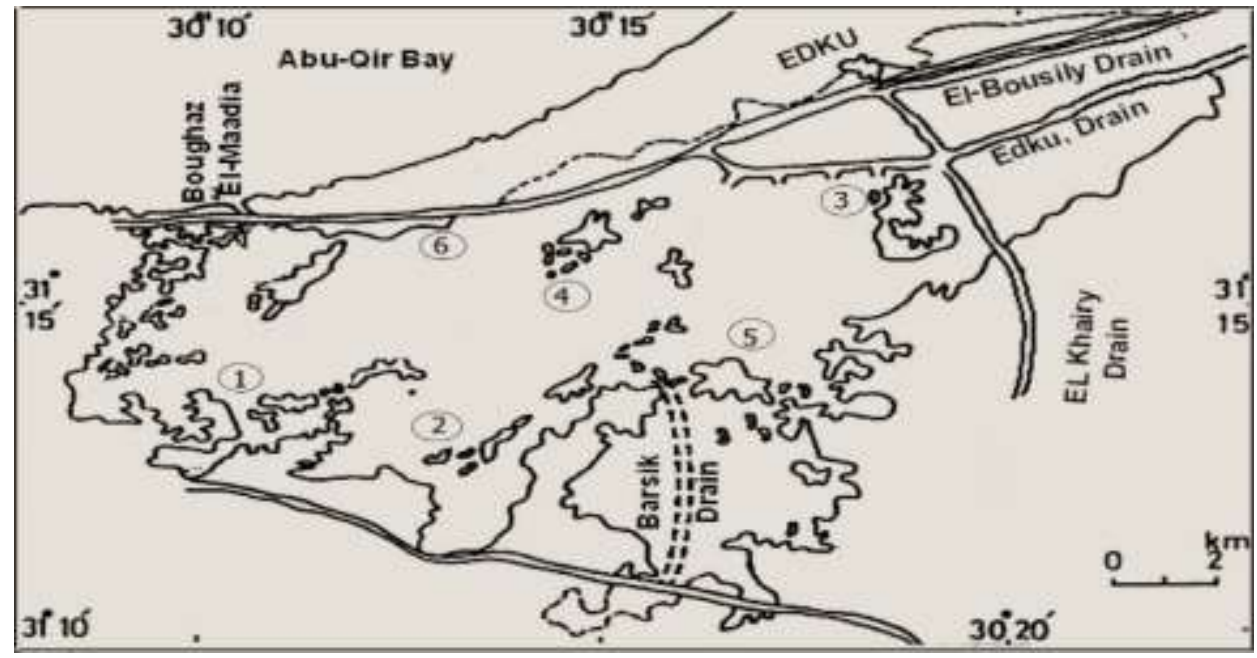

Fig 1: Edku Lake maps clear study stations and main drain canals

The lake can be divided into three ill-defined basins; eastern, central and western. Edku Lake receives huge amounts of drainage water from four main drains, namely, Edku, El Bousily, El Khairy and Bersik as shown in Fig. (1), which open into the eastern basin of the lake (Okbah and El-Gohary, 2002). The drainage water contains unspecified quantities of urban, industrial and agricultural chemicals from the Beheira Governorate and beyond. Based on the diffuse sources of pollution many chemicals from human activities would be present in the

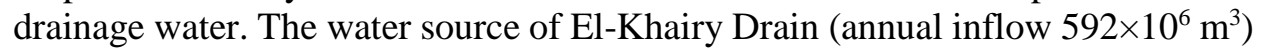
is from three drainage waters coming from El Bousily, Edku and Damanhour subdrains, transporting domestic, agricultural and industrial wastes, as well as the drainage water of many fish farms (Badr and Hussein, 2010). While, Barsik Drain (annual inflow $348 \times 10^{6} \mathrm{~m}^{3}$ ) transports mainly agricultural drainage water to the lake. The lake also receives sea water at its north western part through Boughaz El-Maadia from Abu kir Bay. 


\section{Sampling}

Sampling stations are shown in Table 1 and Figure 1. Twenty-four surface water samples were collected from sex stations using motor boat during four seasons through 2017. Location of selected stations were determined using Geographic Positioning System (GPS). For water quality analyses, water samples were taken at $0-20 \mathrm{~cm}$ below the surface, then it kept in acid cleaned stoppered Polyethylene plastic bottles $(500 \mathrm{ml})$ for later examination, then kept refrigerated and transferred in ice boxes to the laboratory (APHA, 2000). For Bacterial analyses, Bacteria from the water and fish organs (skin, gills and muscle) were isolated using the spread plate technique (APHA, 1995).

Table 1: Location of Sampling stations

\begin{tabular}{cccl}
\hline Station & $\begin{array}{c}\text { Common Station } \\
\text { Name }\end{array}$ & Latitude & / Longitude \\
\hline 1 & El-Tawila & $31^{\circ} 26^{\prime} 24.93^{\prime \prime} \mathrm{N}$ & $30^{\circ} 23^{\prime} 48.89^{\prime \prime} \mathrm{E}$ \\
2 & El-Shlachel & $31^{\circ} 24^{\prime} 01.23^{\prime \prime} \mathrm{N}$ & $30^{\circ} 21^{\prime} 96.90^{\prime \prime} \mathrm{E}$ \\
3 & Abu Hummus drain & $31^{\circ} 15^{\prime} 48.15^{\prime \prime} \mathrm{N}$ & $30^{\circ} 13^{\prime} 57.94^{\prime \prime} \mathrm{E}$ \\
4 & El-Kanaess & $31^{\circ} 25^{\prime} 33.26^{\prime \prime} \mathrm{N}$ & $30^{\circ} 20^{\prime} 65.20^{\prime \prime} \mathrm{E}$ \\
5 & Edko Pumps & $31^{\circ} 15^{\prime} 23.25^{\prime \prime} \mathrm{N}$ & $30^{\circ} 13^{\prime} 42.64^{\prime \prime} \mathrm{E}$ \\
6 & Nakhnookh & $31^{\circ} 16^{\prime} 43.17^{\prime} \mathrm{N}$ & $30^{\circ} 14^{\prime} 42.90^{\prime \prime} \mathrm{E}$ \\
\hline
\end{tabular}

\section{Methods of analyses}

During sampling, temperature and $\mathrm{pH}$ were measured using glass electrode Digital Mini-pH-meter (Model 55). Salinity, total dissolved solid and electrical conductivity were measured by salinity-conductivity meter (model YSI EC 300). dissolved oxygen was measured using a digital oxygen meter (Aqua-lytic OX24). Total ammonia $\left(\mathrm{NH}_{4}-\mathrm{N}\right)$ concentration was measured by Hach Comparison Apparatus (HCA) following the method reported by APHA (2000).

Laboratory analyses, Total alkalinity $(\mathrm{mg} / \mathrm{l})$ was measured by titration method according to APHA (2000). Nitrite, $\mathrm{NO}_{2}-\mathrm{N}(\mathrm{mg} / \mathrm{l})$ was measured by Diazotizing method at $543 \mathrm{~nm}$. Nitrate, $\mathrm{NO}_{3}-\mathrm{N}(\mathrm{mg} / \mathrm{l})$ was determined by Phenoldisulphonic acid method at $410 \mathrm{~nm}$ (APHA, 2000). Orthophosphorus $(\mathrm{mg} / \mathrm{l})$, Total phosphorus $(\mathrm{mg} / \mathrm{l})$ and chlorophyll- $a(\mu \mathrm{g} / \mathrm{l})$ concentration were determined photometrically using was measured 
according to APHA (2000) using spectrophotometer Thermo Electron Corporation (model Nicolet Evolution 100).

For Bacterial analyses, one milliliter of the water sample was serially diluted in sterile peptone water and plated. Skin and muscle contents of tilapia fish were taken aseptically, I cm of skin and $1 \mathrm{~g}$ of muscle was homogenized separately in $9 \mathrm{ml}$ sterile peptone water, the homogenized samples were then diluted using 10- fold serial dilution up to $10^{5}$ in sterile peptone water. Total bacterial count and coliform group were estimated on plate count agar and Mackonky agar (Oxoid), respectively according to APHA (1995). Three Petri-dishes from dilutions were incubated for total bacterial count and coliform group at $37{ }^{\circ} \mathrm{C}$ for 24 hours.

The statistical analysis was applied according to Sendector and Cochran (1982). Differences between means were tested at 5\% probability level according to Duncan's new multiple rang test (Duncan, 1955). All statistical evaluations were done using SPSS computer program according to Dytham (1999).

\section{RESULTS And DISCUSSION}

\section{Physicochemical parameters and nutrients of the lake water}

The changes to the aquatic environment can be easily detected through the lake water quality monitoring and so monitoring on different aspects of water quality over time allows a complete picture of the status of water resource. All the physical, chemical and biological parameters are to be measured to investigate the degree of stress of the aquatic ecosystem (Pal et al., 2015).

Physicochemical parameters (temperature, $\mathrm{pH}$, salinity, DO \& T. Alk.), nutrients $\left(\mathrm{NH}_{4}, \mathrm{NO}_{2}, \mathrm{NO}_{3}, \mathrm{OP}_{4}^{-2} \& \mathrm{TP}\right)$ and chlorophyll a (Chl-a) in all stations are tabulated in Tables $(2 \& 3)$ to assess water quality of the lake. Temporal and spatial changes of parameters (based on average value) were given in Fig. (2).

Water quality parameters of Edku lake were cleared significant difference $(\mathrm{p}<0.05)$ among stations, seasons and their interaction except dissolved oxygen not had significant difference $(p>0.05)$ of stations and seasons interaction.

Temperature is one of the most important factors affecting the physiology, growth, reproduction and metabolism of tilapia. The optimum temperature range for normal development, reproduction and growth of tilapia is about $25-32^{\circ} \mathrm{C}$, depending on the fish species (Chervinski, 1982). The seasonality fluctuation in the lake water temperature was ranged between $18.5^{\circ} \mathrm{C}$ to $31{ }^{\circ} \mathrm{C}$ during the study period. 
$\mathrm{pH}$ values have an important role in the most life processes in aquatic system which can be reflect the productivity and pollution level of the aquatic ecology. It is more important for determining the corrosive nature of water (Okbah et al., 2017). Water $\mathrm{pH}$ variable had indirect toxic effects on aquatic biota through changes to the toxicity of several contamination (Abu Khatit et al., 2017).

From Table (2) and Fig. (2) the smallest $\mathrm{pH}$ value was recorded in winter (7.8) at stations 3 and 4, these results may be due to the increase of organic matter in these stations which nearest from drains enters of (El Bosily, $\mathrm{EdKu}$ and El Kairy). On the other hand, the highest values were (9.1 and $8.9)$ in summer season at stations $(1 \& 6)$ with the increase of water discharge. These results were agreed with Saeed, 2013 who indicted that $\mathrm{pH}$ of Edku lake lies in the alkaline side. Where the highest values were recorded in summer during the outbreak of chlorophyll "a" biomass and aquatic plants, the lowest $\mathrm{pH}$ values appeared in winter due to the increase of sewage wastewater. The desirable $\mathrm{pH}$ range for most fish species is 6-9 (Barker et al., 2009).

Okbah et al. (2017) showed that $\mathrm{pH}$ variation between stations may be controlled by the density of phytoplankton count and the water quality inflow to the lake, where the phytoplankton population increasing cause an increase in the $\mathrm{pH}$ value and oxygen super saturation due to the high photosynthetic activity by green and blue green algae (El-Sherif and Mahmoud, 1991), with reducing of $\mathrm{CO}_{2}$ amount in water (Masoud et al., 2001).

Salinity is one of the most important factors that affect the species dynamics, faunal composition, distribution and diversity of bottom population in many aquatic ecosystems (Darwish, 2016). The lake salinity, electrical conductivity and total dissolved solid were varied between 1.3 $\mathrm{g} / 1,2.47 \mathrm{mS} / \mathrm{cm} \& 1.273 \mathrm{mg} / \mathrm{l}$, respectively as the lowest value at station 1 and $2.8 \mathrm{~g} / 1,4.93 \mathrm{mS} / \mathrm{cm} \mathrm{\&} 3.1 \mathrm{mg} / \mathrm{l}$, respectively as the highest value at stations $5 \& 4$. Generally, the salinity of the water lake raised in the summer season recorded significantly difference $(p<0.05)$ more than in the rest of the seasons, and this may be due to the high temperature and increasing the evaporation rates which agree with (Farouk, $2009 \&$ El Morshedy, 2017).

Dissolved oxygen (DO) is one of the most important parameters in the lake ecosystem. Oxygen depletion can cause large changes in the population of fish, leading, in extreme cases, to the massive fish kill (Barica and Mathias, 1979). Oxygen content can be used as an indicator of organic loading, nutrient input and biological activity (Shaker, 2008). The level of dissolved oxygen in the northern Lakes of Egypt is affected by 
Table 2: physical parameters of Edku lake water in the study stations.

\begin{tabular}{|c|c|c|c|c|c|c|c|}
\hline station & season & Temp & $\mathrm{pH}$ & Salinity & $\mathrm{EC}$ & TDS & $\mathrm{DO}$ \\
\hline \multirow{4}{*}{1} & Winter & $18.5 \pm 0.115 \mathrm{~h}$ & $8.1 \pm 0.058 \mathrm{i}$ & $1.3 \pm 0.03 \mathrm{i}$ & $2.47 \pm 0.115 \mathrm{i}$ & $1.273 \pm 0.028 \mathrm{n}$ & $6.5 \pm 0.115 \mathrm{a}$ \\
\hline & Springe & $23.5 \pm 0.058 \mathrm{e}$ & $8.6 \pm 0.033 \mathrm{de}$ & $1.3 \pm 0.03 \mathrm{i}$ & $2.70 \pm 0.058 \mathrm{~h}$ & $1.390 \pm 0.038 \mathrm{~lm}$ & $6.0 \pm 0.404 \mathrm{bc}$ \\
\hline & Summer & $30.5 \pm 0.289 b$ & $8.7 \pm 0.033 \mathrm{de}$ & $1.6 \pm 0.06$ ef & $2.83 \pm 0.033 \mathrm{~h}$ & $1.720 \pm 0.042 \mathrm{ghi}$ & $4.5 \pm 0.058 \mathrm{i}$ \\
\hline & Autumn & $24.6 \pm 0.173 \mathrm{~d}$ & $8.9 \pm 0.012 \mathrm{~b}$ & $1.5 \pm 0.03 \mathrm{gh}$ & $2.77 \pm 0.033 \mathrm{~h}$ & $1.600 \pm 0.058$ hijk & $5.5 \pm 0.0001 \mathrm{de}$ \\
\hline \multirow{4}{*}{2} & Winter & $19 \pm 0.058 \mathrm{gh}$ & $8.2 \pm 0.033 \mathrm{hi}$ & $1.5 \pm 0.03 \mathrm{fgh}$ & $3.10 \pm 0.058 \mathrm{~g}$ & $1.587 \pm 0.030 \mathrm{ijk}$ & $6.0 \pm 0.058 \mathrm{bc}$ \\
\hline & Springe & $23.5 \pm 0.231 \mathrm{e}$ & $8.3 \pm 0.029 \mathrm{~h}$ & $1.4 \pm 0.03 \mathrm{~h}$ & $3.13 \pm 0.033 \mathrm{fg}$ & $1.393 \pm 0.047 \mathrm{~lm}$ & $5.4 \pm 0.115$ ef \\
\hline & Summer & $30.5 \pm 0.346 b$ & $8.4 \pm 0.033 \mathrm{fg}$ & $1.8 \pm 0.03 \mathrm{~d}$ & $3.34 \pm 0.032 \mathrm{e}$ & $1.907 \pm 0.058 \mathrm{f}$ & $3.8 \pm 0.058 \mathrm{jk}$ \\
\hline & Autumn & $24.5 \pm 0.115 \mathrm{~d}$ & $8.4 \pm 0.058 \mathrm{~g}$ & $1.6 \pm 0.03 \mathrm{fg}$ & $3.33 \pm 0.033 \mathrm{e}$ & $1.750 \pm 0.029 \mathrm{gh}$ & $4.7 \pm 0.088 \mathrm{hi}$ \\
\hline \multirow{4}{*}{3} & Winter & $19.0 \pm 0.289 \mathrm{gh}$ & $7.8 \pm 0.033 \mathrm{j}$ & $1.6 \pm 0.03 \mathrm{fg}$ & $3.13 \pm 0.033 \mathrm{fg}$ & $1.657 \pm 0.023 \mathrm{hij}$ & $5.5 \pm 0.0001 \mathrm{de}$ \\
\hline & Springe & $23.5 \pm 0.058 \mathrm{e}$ & $8.2 \pm 0.033 \mathrm{hi}$ & $1.5 \pm 0.03 \mathrm{fgh}$ & $3.03 \pm 0.033 \mathrm{~g}$ & $1.517 \pm 0.046 \mathrm{jkl}$ & $4.9 \pm 0.058 \mathrm{gh}$ \\
\hline & Summer & $30.5 \pm 0.231 \mathrm{~b}$ & $8.3 \pm 0.033 \mathrm{~h}$ & $2.2 \pm 0.03 \mathrm{c}$ & $3.17 \pm 0.033 \mathrm{fg}$ & $2.300 \pm 0.058 \mathrm{~d}$ & $2.8 \pm 0.0001 \mathrm{~m}$ \\
\hline & Autumn & $25.6 \pm 0.231 \mathrm{c}$ & $8.8 \pm 0.044 \mathrm{bc}$ & $1.9 \pm 0.03 \mathrm{~d}$ & $3.67 \pm 0.033 \mathrm{~d}$ & $1.950 \pm 0.064$ ef & $3.9 \pm 0.058 \mathrm{j}$ \\
\hline \multirow{4}{*}{4} & Winter & $18.5 \pm 0.058 \mathrm{~h}$ & $8.2 \pm 0.033 \mathrm{hi}$ & $2.2 \pm 0.03 \mathrm{c}$ & $4.57 \pm 0.033 b$ & $2.730 \pm 0.064 \mathrm{~b}$ & $5.0 \pm 0.058 \mathrm{gh}$ \\
\hline & Springe & $22.5 \pm 0.346 \mathrm{f}$ & $8.5 \pm 0.033 \mathrm{fg}$ & $2.1 \pm 0.03 \mathrm{c}$ & $4.17 \pm 0.033 \mathrm{c}$ & $2.100 \pm 0.058 \mathrm{e}$ & $4.5 \pm 0.115 \mathrm{i}$ \\
\hline & Summer & $31 \pm 0.173 \mathrm{ab}$ & $8.6 \pm 0.033 \mathrm{def}$ & $2.8 \pm 0.03 \mathrm{a}$ & $4.93 \pm 0.033 \mathrm{a}$ & $3.100 \pm 0.058 \mathrm{a}$ & $2.6 \pm 0.058 \mathrm{~m}$ \\
\hline & Autumn & $25.7 \pm 0.289 \mathrm{c}$ & $8.7 \pm 0.044 \mathrm{de}$ & $2.5 \pm 0.03 \mathrm{~b}$ & $4.50 \pm 0.058 \mathrm{~b}$ & $2.583 \pm 0.017 \mathrm{c}$ & $3.6 \pm 0.115 \mathrm{jk}$ \\
\hline \multirow{4}{*}{5} & Winter & $19.5 \pm 0.058 \mathrm{~g}$ & $7.8 \pm 0.044 \mathrm{j}$ & $1.9 \pm 0.03 \mathrm{~d}$ & $3.33 \pm 0.033 \mathrm{e}$ & $2.000 \pm 0.058 \mathrm{ef}$ & $6.2 \pm 0.115 \mathrm{ab}$ \\
\hline & Springe & $24.5 \pm 0.173 \mathrm{~d}$ & $8.1 \pm 0.058 \mathrm{i}$ & $1.8 \pm 0.07 \mathrm{~d}$ & $3.27 \pm 0.033$ ef & $2.100 \pm 0.058 \mathrm{e}$ & $5.5 \pm 0.115 \mathrm{de}$ \\
\hline & Summer & $31.5 \pm 0.346 \mathrm{a}$ & $8.5 \pm 0.033 \mathrm{fg}$ & $2.2 \pm 0.06 \mathrm{c}$ & $4.14 \pm 0.081 \mathrm{c}$ & $2.300 \pm 0.058 \mathrm{~d}$ & $3.5 \pm 0.088 \mathrm{kl}$ \\
\hline & Autumn & $26 \pm 0.404 \mathrm{c}$ & $8.6 \pm 0.029 \mathrm{ef}$ & $2.2 \pm 0.03 \mathrm{c}$ & $4.17 \pm 0.033 \mathrm{c}$ & $2.300 \pm 0.058 \mathrm{~d}$ & $4.7 \pm 0.088 \mathrm{hi}$ \\
\hline \multirow{3}{*}{6} & Winter & $19.5 \pm 0.289 \mathrm{~g}$ & $8.1 \pm 0.058 \mathrm{i}$ & $1.6 \pm 0.03 \mathrm{ef}$ & $3.33 \pm 0.032 \mathrm{e}$ & $1.610 \pm 0.055$ hijk & $5.8 \pm 0.088 \mathrm{~cd}$ \\
\hline & Springe & $23.5 \pm 0.115 \mathrm{e}$ & $8.8 \pm 0.060 \mathrm{bc}$ & $1.5 \pm 0.03 \mathrm{gh}$ & $3.10 \pm 0.058 \mathrm{~g}$ & $1.467 \pm 0.033 \mathrm{kl}$ & $5.1 \pm 0.058 \mathrm{fg}$ \\
\hline & Summer & $31.5 \pm 0.231 \mathrm{a}$ & $9.1 \pm 0.058 \mathrm{a}$ & $1.9 \pm 0.03 \mathrm{~d}$ & $4.10 \pm 0.058 \mathrm{~b}$ & $1.953 \pm 0.044 \mathrm{ef}$ & $3.2 \pm 0.1151$ \\
\hline & Autumn & $26.2 \pm 0.115 \mathrm{c}$ & $8.7 \pm 0.058 \mathrm{~cd}$ & $1.7 \pm 0.06 \mathrm{e}$ & $3.83 \pm 0.033 \mathrm{c}$ & $1.850 \pm 0.069 \mathrm{fg}$ & $4.4 \pm 0.058 \mathrm{i}$ \\
\hline \multicolumn{2}{|c|}{ Two Way ANOVA } & & & & $P$ value & & \\
\hline \multicolumn{2}{|c|}{ Station } & 0.0001 & 0.0001 & 0.0001 & 0.0001 & 0.0001 & 0.0001 \\
\hline \multicolumn{2}{|c|}{ Season } & 0.0001 & 0.0001 & 0.0001 & 0.0001 & 0.0001 & 0.0001 \\
\hline \multicolumn{2}{|c|}{ Station $\times$ Season } & 0.001 & 0.0001 & 0.0001 & 0.0001 & 0.0001 & 0.140 \\
\hline
\end{tabular}

Means having the same letter in the same column are not significantly different at $\mathrm{P}<0.05$ 
Table 3: Chemical parameters of Edku lake water in the study stations.

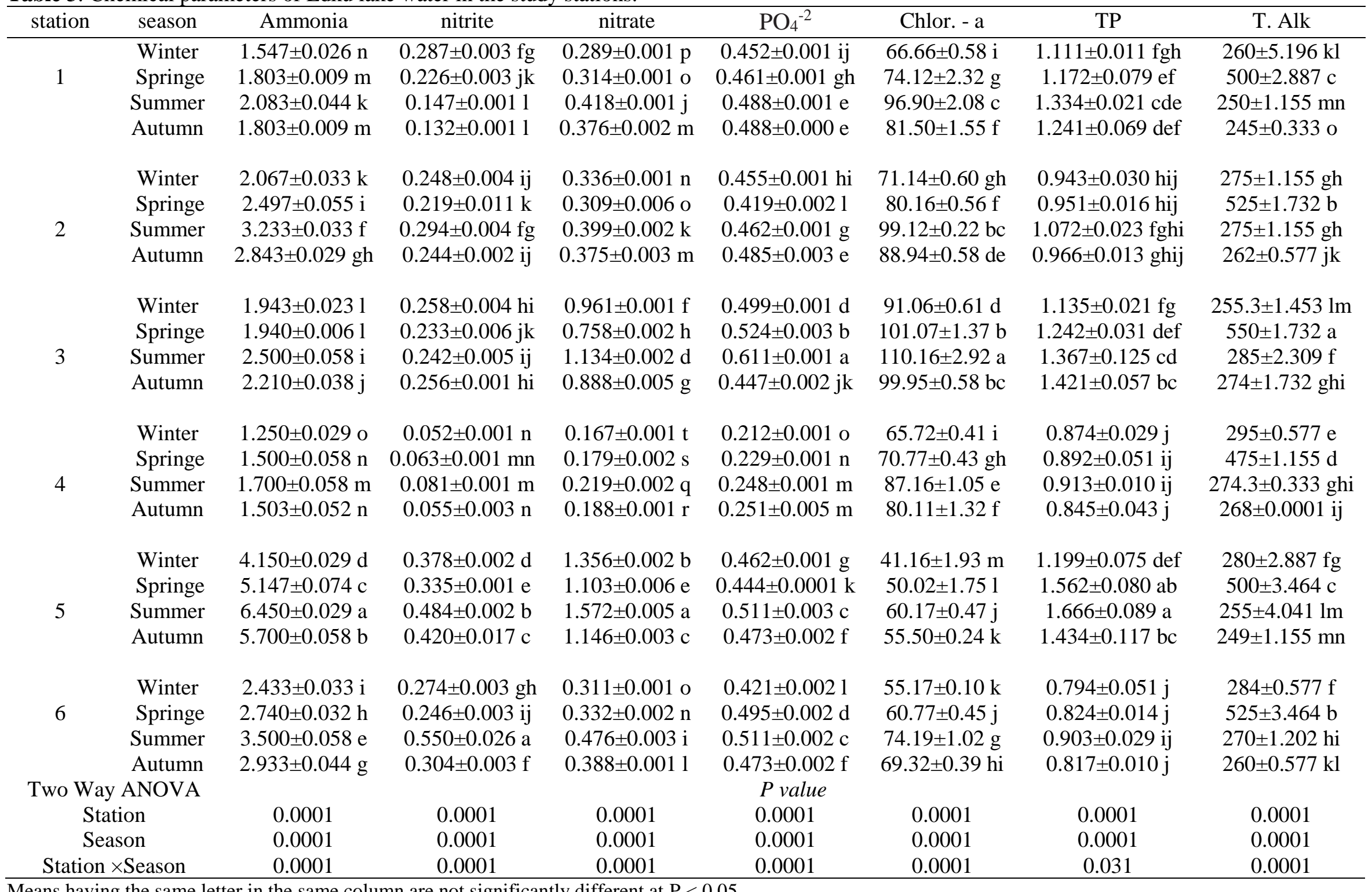

Means having the same letter in the same column are not significantly different at $\mathrm{P}<0.05$ 
many factors such as temperature, wind, photosynthetic activity of phytoplankton communities, and respiration of heterotrophic, autotrophic organisms and decomposition of organic matter (Zaghloul et al., 2005).

Dissolved oxygen of the lake fluctuated among seasons depending on water temperature where during winter ranged from 5.0 to $6.5 \mathrm{mg} / \mathrm{l}$, in spring ranged between 4.5 to $6.0 \mathrm{mg} / \mathrm{l}$ and ranged from 2.6 to $4.5 \mathrm{mg} / \mathrm{l}$ during summer, while in autumn ranged between 3.6 and $5.5 \mathrm{mg} / \mathrm{l}$. These results cleared that the highest values of dissolved oxygen recorded during winter while summer recorded the lowest values. Boyed and Tucker (1998) reported that the dissolved of oxygen from air to water decrease with increasing temperature.

Also, the DO results had showed the lowest average values at stations (4 then 3) (Fig. 2), this may be attributed to microbial degradation by oxygen consumption of organic matter loaded by higher amount of sewage wastewater and drainage water poured in these areas from the drains (El Bosily, EdKu and El Khairy) which agree with (Farouk, 2009).

In aquatic environmental, ammonia can be product from several sources such as sewage effluents, industrial wastes agricultural run-off and decomposition of biologic wastes (Randall and Tsui, 2002). It may result from the bacterial decomposition of organic matter containing nitrogen (Shakweer, 2005). Nitrogenous compounds, nitrite and nitrate, despite the seriousness of these compounds, it is one of the specific compounds to the water where fertility is considered alongside of the most important sources of ammonia nitrogen for algae and aquatic plants.

The results of ammonia $\left(\mathrm{NH}_{4}-\mathrm{N}\right)$ in the lake were ranged between 1.54 - $2.08 \mathrm{mg} / \mathrm{l}, 2.06-3.23 \mathrm{mg} / \mathrm{l}, 1.94-2.5 \mathrm{mg} / \mathrm{l}, 1.25-1.7 \mathrm{mg} / \mathrm{l}, 4.15-6.45 \mathrm{mg} / \mathrm{l}$ and $2.43-3.5 \mathrm{mg} / \mathrm{l}$ for the study stations from 1 to 6 respectively. While, Nitrite $\left(\mathrm{NO}_{2}-\mathrm{N}\right)$ values of the lake ranged between minimum value of 0.052 $\mathrm{mg} / \mathrm{l}$ at station 4 during winter and maximum value of $0.484 \mathrm{mg} / \mathrm{l}$ at stations 5 during summer, and lake nitrate $\left(\mathrm{NO}_{3}-\mathrm{N}\right)$ content followed the same trend, where it recorded the highest value in summer $(1.572 \mathrm{mg} / \mathrm{l})$ and the lowest one in winter $(0.167$ and $0.12 \mathrm{mg} / \mathrm{l})$.

These results of inorganic nitrogen compounds indicated that the highest values were recorded at stations $(5,3 \& 2)$ nearest the drains to increasing accumulated organic compounds in them and this agree with Saeed (2013) and El Morshedy (2017). Also, noted that the highest values were recorded during summer which may be due to the un ionized ammonia depending on temperature, i.e. the rate of the ammonification process increases converting the organic matter to ammonia, especially at high temperature. 
These results agree with those obtained by El Morshedy (2017) and Abu Khatit et al. (2017) who reported attributed that results to the high rate of microbial activity associated with high organic compound and in turn high nitrogen content.

Phosphorus $(\mathrm{P})$ is the rate-limiting nutrient in the eutrophication of most freshwater ecosystems Mainston and Parr (2002). Schlotfeldt and Alderman (1995) suggested a range of phosphate from 0.6 to $1.0 \mathrm{mg} / \mathrm{l}$ for freshwater species.

Ortho phosphate results were ranged from the maximum value of 0.611 $\mathrm{mg} / \mathrm{l}$ in summer and the minimum value of $0.212 \mathrm{mg} / \mathrm{l}$ in winter. Where, station 3 was had the significantly $(\mathrm{p}>0.05)$ increase than other stations of reactive phosphate are mostly because of drainage water enriched with phosphorous compounds. The concentration of all nutrients $\left(\mathrm{NH}_{4}, \mathrm{NO}_{2}\right.$, $\left.\mathrm{NO}_{3}, \mathrm{OP}_{4} \& \mathrm{TP}\right)$ in this study were higher than those recorded in the same lake by (Saeed, 2013; Okbah et al., 2017\& El Morshedy, 2017).

Chlorophyll "a" is an important indicator for the presence of algae and it is often considered as the dominant factor for assessing eutrophication (Zhou et al., 2004). Chlorophyll "a" concentration in Edku lake varied from $41.16 \mu \mathrm{g} / \mathrm{l}$ in winter to $110.16 \mu \mathrm{g} / \mathrm{l}$ in summer. These results are in agreement with Abel (1998) and Shaker (2006), who reported that the chlorophyll "a" concentration is depending on many factors in water like water temperatures, algal photosynthetic activities and macronutrient content. Also, French and Petticrew (2007) found Positive associations between instantaneous (chlorophyll "a") and temperature that forecast changes in phytoplankton productivity even if nutrient loading rates remain constant.

the maxima average of chlorophyll "a" was recorded at station 3 during the study because it at nearest of the mains drains (Barsik, Edku and El Khairy) where the high amounts of nutrient salts, Fig. (3) and this agree with Abu Khatita et al. (2017) who found the same investigation in Manzala lake and indicated that there is good relation between chlorophyll "a" and nutrient salts (ammonia, and orthophosphate) because nutrient concentrations led to an increase in algal density and consequently, severe eutrophic conditions. Generally, chlorophyll "a" is used as an indicator for the fertility of water and phytoplankton. Increases of nutrient in the water is leading to increases phytoplankton and chlorophyll "a".

The highest value of total phosphorus was $1.666 \mathrm{mg} / \mathrm{l}$ at station 5 during summer while the lowest value of it was $0.794 \mathrm{mg} / \mathrm{l}$ at station 6 . The 
Farouk, A. / Egy. J. Aquac. 8 (2): 29-56(2018)
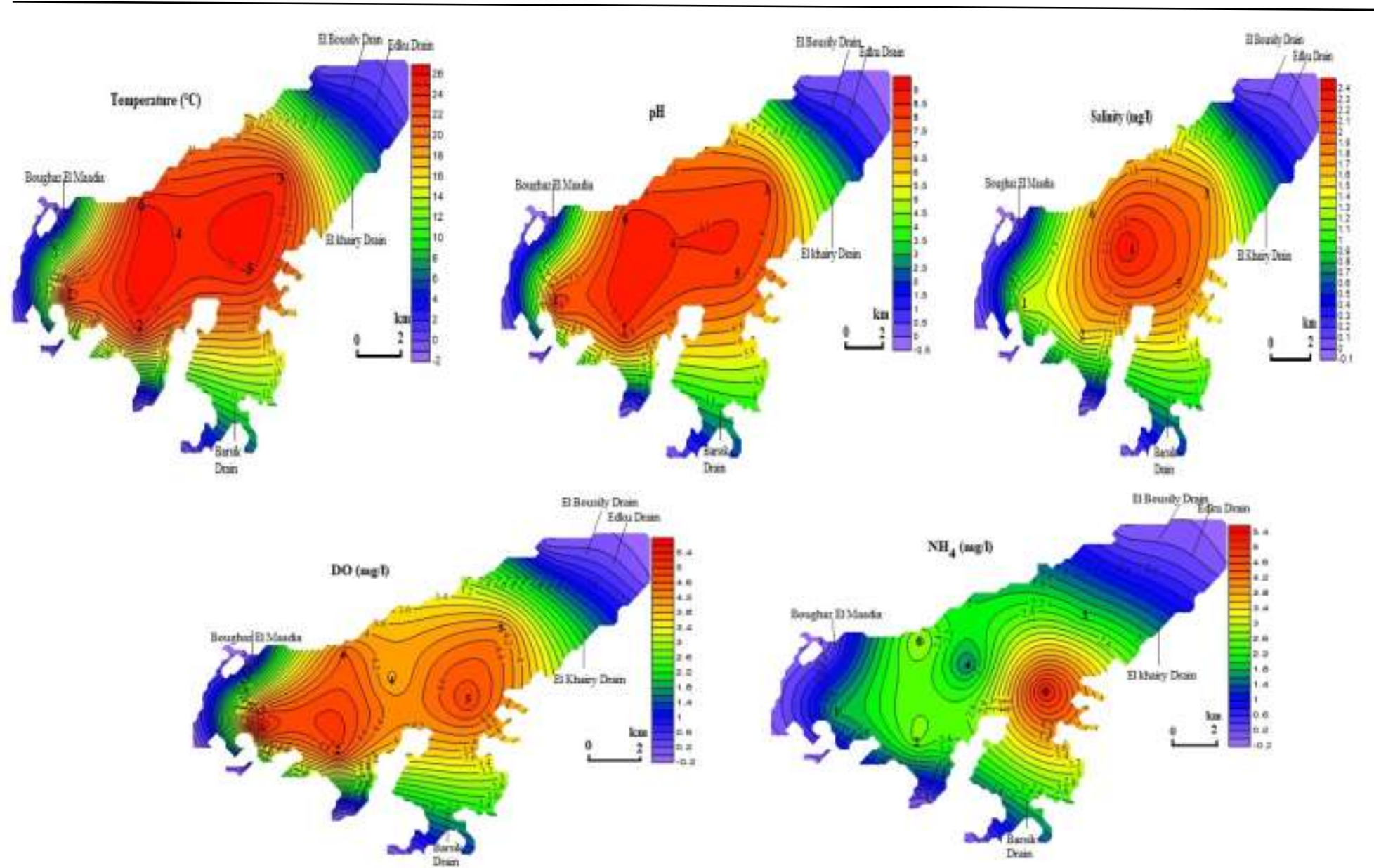

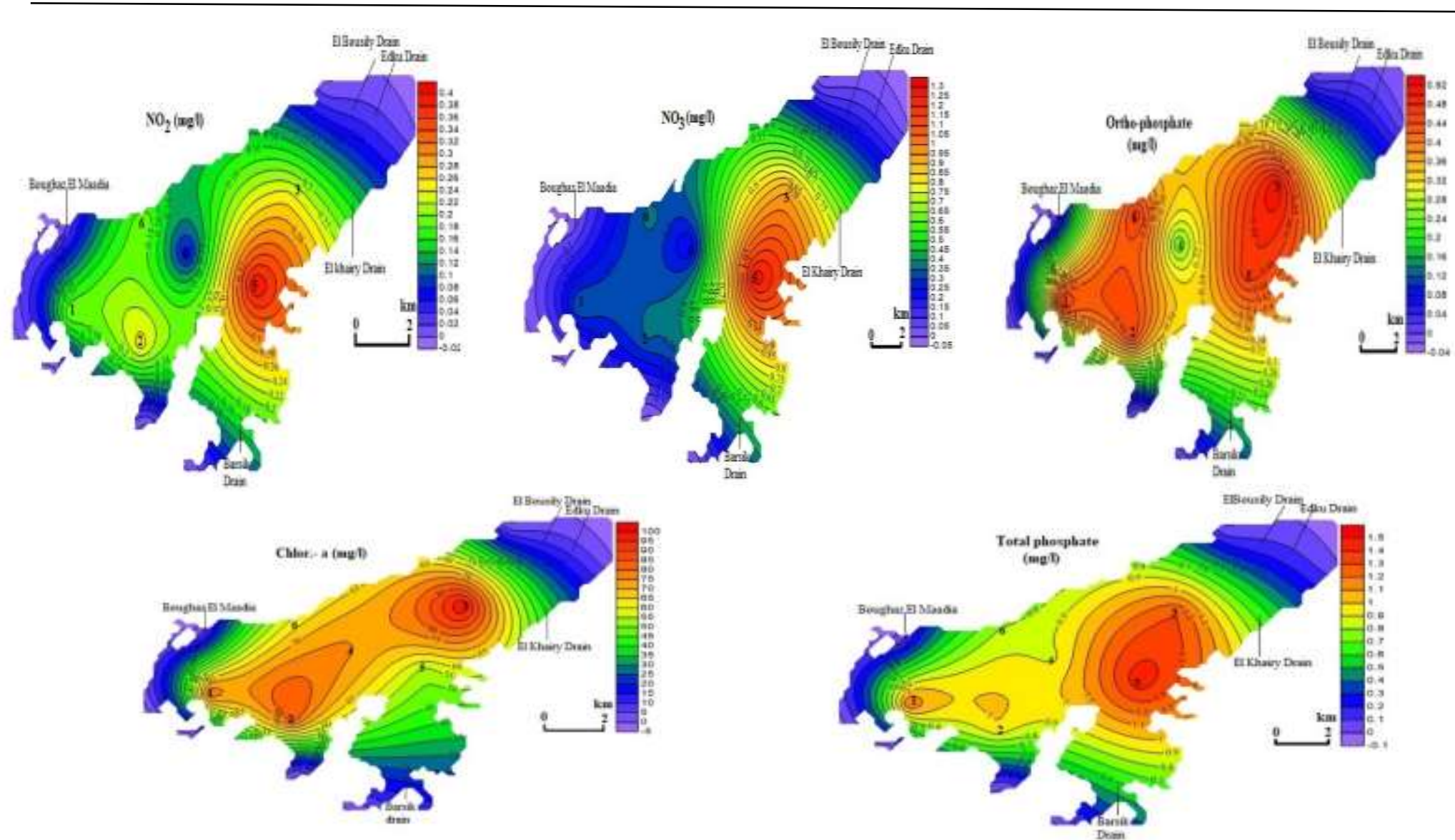

Fig. 2: Lateral distribution based on average values of different parameters in water samples of Edku lake. 
highest concentration appeared in stations which are subjected to direct influx of drainage water and sewage wastewater.

As illustrated in Table (3), total alkalinity of the lake varied between the maxima of $550 \mathrm{mg} / \mathrm{l}$ at station 3 during springe and the minima of $245 \mathrm{~m} / \mathrm{l}$ at station 1 during autumn. these finding clear that the total alkalinity in the lake water are depends on organic compounds content in water discharge to the lake and the main drains canals, Fig. (2).

Interpretation of lake water quality average results (Fig. 2) were done according to Pooja Devi (2013) who recommended water-quality criteria for fishery for getting high yield via applying minimum input. Where the results of temperature, $\mathrm{pH}$, dissolved oxygen and phosphorus were indicated in suitable range at all study stations. Results of ammonia and nitrite were indicated in stress range for fish while nitrate results were lied as desirable results. Also, total alkalinity results recorded in stress range for fish.

\section{Bacteriological load quality}

Bacteriological quality is of importance to public health since it directly relates to fish spoilage and may cause food poisoning. It is therefore important to monitor the quality of harvested freshwater fish (Ibemenuga and Okeke, 2014). In addition to, the bacteriological examination of the source of water on the fish is very necessary in order to detect the kind of bacteria being transferred into the fish environments. It can serve as a guide to monitor and protect our fish quality as well as our health (Abdel-Hamid, 2017).

Data in Table (4) addresses the total bacterial count and coliform group in water and tissues (skin \& muscle) of tilapia species at different stations of Edku lake. Water results shows that the highest values of total bacterial count and coliform group were recorded at station 5 and 3 as $63.17 \& 27.17$ $\times 10^{5} \mathrm{CFU} / \mathrm{ml}$ and $10.77 \& 5.35 \times 10^{4} \mathrm{CFU} / \mathrm{ml}$, respectively, while lowest values were $2.1 \& 0.33 \times 10^{5} \mathrm{CFU} / \mathrm{ml}$ respectively at station 4 in middle of the lake in side to stations $(1,2 \& 6)$ were recoded the lowest values also, Fig, (3). The highest bacterial load at stations $(5 \& 3)$ related to their site nearest from drains mouth (Edku, El Bousily, El Khairy \& Barsik) as shows in Fig. (2) and this gives indicators on pollution of these stations, which agree with Abdel-Hamid (2017) investigated pollution of El-Genka station in Manzala lake as result to bacterial load increasing. This can also be attributed to non-processed drainage by different drains to lake water where were had he high loads of organic matter and bacteria this finding is in concurrent with Mousa et al. (2018) and Anand et al. (2006) who stated 
Table 4: Changes in total bacterial count and coliform group in water and Tilapia tissues (skin \& muscle) of Edku lake at the study stations.

\begin{tabular}{|c|c|c|c|c|c|c|c|}
\hline station & season & TC water & CF water & TC Skin & TC Muscle & CF Skin & CF Muscle \\
\hline \multirow{4}{*}{1} & Winter & $2.60 \pm 0.058 \mathrm{o}$ & $0.40 \pm 0.029$ no & $3.33 \pm 0.202 \mathrm{p}$ & $0.47 \pm 0.046 \mathrm{k}$ & $0.74 \pm 0.040 \mathrm{~lm}$ & $0.31 \pm 0.006 \mathrm{q}$ \\
\hline & Springe & $2.88 \pm 0.040$ no & $0.51 \pm 0.006 \mathrm{mno}$ & $4.19 \pm 0.104$ nop & $0.69 \pm 0.023 \mathrm{jk}$ & $0.96 \pm 0.026 \mathrm{~lm}$ & $0.78 \pm 0.006 \mathrm{k}$ \\
\hline & Summer & $5.55 \pm 0.196 \mathrm{j}$ & $0.87 \pm 0.062 \mathrm{kl}$ & $7.97 \pm 0.445 \mathrm{j}$ & $1.13 \pm 0.075 \mathrm{jk}$ & $1.77 \pm 0.092 \mathrm{k}$ & $1.33 \pm 0.012 \mathrm{~g}$ \\
\hline & Autumn & $4.79 \pm 0.035 \mathrm{k}$ & $0.66 \pm 0.012 \mathrm{klmno}$ & $6.08 \pm 0.046 \mathrm{klm}$ & $0.89 \pm 0.040 \mathrm{jk}$ & $1.17 \pm 0.0461$ & $0.91 \pm 0.006 \mathrm{i}$ \\
\hline \multirow{4}{*}{2} & Winter & $2.75 \pm 0.087$ no & $0.43 \pm 0.006 \mathrm{mno}$ & $4.75 \pm 0.081 \mathrm{n}$ & $0.56 \pm 0.040 \mathrm{jk}$ & $1.02 \pm 0.012 \mathrm{~lm}$ & $0.11 \pm 0.006 \mathrm{t}$ \\
\hline & Springe & $3.11 \pm 0.006 \mathrm{n}$ & $0.57 \pm 0.012 \mathrm{lmno}$ & $5.35 \pm 0.202 \mathrm{lmn}$ & $0.89 \pm 0.058 \mathrm{jk}$ & $1.77 \pm 0.060 \mathrm{k}$ & $0.230 \pm 0.006 \mathrm{~s}$ \\
\hline & Summer & $4.97 \pm 0.075 \mathrm{k}$ & $0.93 \pm 0.012 \mathrm{k}$ & $7.73 \pm 0.214 \mathrm{j}$ & $1.83 \pm 0.092 \mathrm{i}$ & $2.99 \pm 0.115 \mathrm{gh}$ & $0.550 \pm 0.006 \mathrm{n}$ \\
\hline & Autumn & $3.87 \pm 0.046 \mathrm{~m}$ & $0.78 \pm 0.006 \mathrm{klm}$ & $6.11 \pm 0.127 \mathrm{klm}$ & $1.05 \pm 0.087 \mathrm{jk}$ & $2.15 \pm 0.023 \mathrm{jk}$ & $0.430 \pm 0.006 \mathrm{o}$ \\
\hline \multirow{4}{*}{3} & Winter & $14.55 \pm 0.225 \mathrm{~h}$ & $1.66 \pm 0.052 \mathrm{i}$ & $21.75 \pm 0.260 \mathrm{~h}$ & $3.88 \pm 0.029 \mathrm{~h}$ & $2.37 \pm 0.017 \mathrm{ij}$ & $0.787 \pm 0.003 \mathrm{k}$ \\
\hline & Springe & $17.11 \pm 0.075 \mathrm{~g}$ & $2.71 \pm 0.087 \mathrm{~g}$ & $27.17 \pm 0.416 \mathrm{~g}$ & $4.79 \pm 0.035 \mathrm{~g}$ & $3.33 \pm 0.191 \mathrm{~g}$ & $1.250 \pm 0.006 \mathrm{~h}$ \\
\hline & Summer & $27.17 \pm 0.098 \mathrm{e}$ & $5.35 \pm 0.214 \mathrm{~d}$ & $39.01 \pm 0.629 \mathrm{e}$ & $7.40 \pm 0.248 \mathrm{~d}$ & $5.16 \pm 0.092 \mathrm{e}$ & $2.660 \pm 0.006 \mathrm{~d}$ \\
\hline & Autumn & $21.89 \pm 0.312 \mathrm{f}$ & $3.79 \pm 0.035 \mathrm{f}$ & $33.13 \pm 0.364 \mathrm{f}$ & $6.07 \pm 0.098 \mathrm{f}$ & $4.24 \pm 0.139 \mathrm{f}$ & $1.877 \pm 0.009 \mathrm{e}$ \\
\hline \multirow{4}{*}{4} & Winter & $2.10 \pm 0.064 \mathrm{p}$ & $0.33 \pm 0.017$ o & $3.55 \pm 0.237$ op & $0.49 \pm 0.035 \mathrm{k}$ & $0.71 \pm 0.052 \mathrm{~m}$ & $0.250 \pm 0.006 \mathrm{r}$ \\
\hline & Springe & $3.99 \pm 0.254 \mathrm{~lm}$ & $0.67 \pm 0.012 \mathrm{klmno}$ & $4.61 \pm 0.165$ no & $0.67 \pm 0.017 \mathrm{jk}$ & $1.11 \pm 0.040 \mathrm{~lm}$ & $0.440 \pm 0.006 \mathrm{o}$ \\
\hline & Summer & $5.45 \pm 0.202 \mathrm{j}$ & $1.63 \pm 0.127 \mathrm{ij}$ & $6.36 \pm 0.202 \mathrm{kl}$ & $1.19 \pm 0.098 \mathrm{j}$ & $2.75 \pm 0.196 \mathrm{hi}$ & $0.787 \pm 0.003 \mathrm{k}$ \\
\hline & Autumn & $4.31 \pm 0.1621$ & $0.94 \pm 0.029 \mathrm{k}$ & $5.11 \pm 0.185 \mathrm{mn}$ & $0.93 \pm 0.035 \mathrm{jk}$ & $2.02 \pm 0.052 \mathrm{jk}$ & $0.580 \pm 0.006 \mathrm{~m}$ \\
\hline \multirow{4}{*}{5} & Winter & $35.55 \pm 0.115 \mathrm{~d}$ & $4.44 \pm 0.242 \mathrm{e}$ & $51.11 \pm 0.716 \mathrm{~d}$ & $6.77 \pm 0.191 \mathrm{e}$ & $6.14 \pm 0.087 \mathrm{~d}$ & $1.780 \pm 0.006 \mathrm{f}$ \\
\hline & Springe & $43.14 \pm 0.087 \mathrm{c}$ & $6.16 \pm 0.156 \mathrm{c}$ & $61.66 \pm 0.312 \mathrm{c}$ & $8.32 \pm 0.271 \mathrm{c}$ & $8.14 \pm 0.341 \mathrm{c}$ & $3.140 \pm 0.006 \mathrm{c}$ \\
\hline & Summer & $63.17 \pm 0.162 \mathrm{a}$ & $10.77 \pm 0.248 \mathrm{a}$ & $88.18 \pm 0.491 \mathrm{a}$ & $14.04 \pm 0.687 \mathrm{a}$ & $13.07 \pm 0.254 \mathrm{a}$ & $5.470 \pm 0.006 \mathrm{a}$ \\
\hline & Autumn & $54.18 \pm 0.098 \mathrm{~b}$ & $8.02 \pm 0.139 \mathrm{~b}$ & $70.07 \pm 0.901 \mathrm{~b}$ & $10.14 \pm 0.283 b$ & $10.07 \pm 0.329 \mathrm{~b}$ & $4.090 \pm 0.006 \mathrm{~b}$ \\
\hline \multirow{4}{*}{6} & Winter & $3.77 \pm 0.087 \mathrm{~m}$ & $0.74 \pm 0.069 \mathrm{klmn}$ & $5.09 \pm 0.191 \mathrm{mn}$ & $0.64 \pm 0.052 \mathrm{jk}$ & $1.08 \pm 0.064 \mathrm{~lm}$ & $0.370 \pm 0.006 \mathrm{p}$ \\
\hline & Springe & $4.88 \pm 0.064 \mathrm{k}$ & $1.33 \pm 0.069 \mathrm{j}$ & $6.88 \pm 0.064 \mathrm{jk}$ & $1.11 \pm 0.075 \mathrm{jk}$ & $2.11 \pm 0.081 \mathrm{jk}$ & $0.650 \pm 0.0061$ \\
\hline & Summer & $7.09 \pm 0.087 \mathrm{i}$ & $2.97 \pm 0.046 \mathrm{~g}$ & $9.19 \pm 0.404 \mathrm{i}$ & $2.29 \pm 0.092 \mathrm{i}$ & $4.12 \pm 0.100 \mathrm{f}$ & $1.340 \pm 0.006 \mathrm{~g}$ \\
\hline & Autumn & $5.75 \pm 0.081 \mathrm{j}$ & $2.02 \pm 0.191 \mathrm{~h}$ & $7.62 \pm 0.195 \mathrm{j}$ & $1.77 \pm 0.393 \mathrm{i}$ & $3.17 \pm 0.121 \mathrm{~g}$ & $0.870 \pm 0.006 \mathrm{j}$ \\
\hline \multicolumn{2}{|c|}{ Two Way ANOVA } & \multicolumn{4}{|c|}{$P$ value } & & \\
\hline \multicolumn{2}{|c|}{ Station } & 0.0001 & 0.0001 & 0.0001 & 0.0001 & 0.0001 & 0.444 \\
\hline \multicolumn{2}{|c|}{ Season } & 0.0001 & 0.0001 & 0.0001 & 0.0001 & 0.0001 & 0.289 \\
\hline \multicolumn{2}{|c|}{ Station $\times$ Season } & 0.0001 & 0.0001 & 0.0001 & 0.0001 & 0.0001 & 0.484 \\
\hline
\end{tabular}

Means having the same letter in the same column are not significantly different at $\mathrm{P}<0.05$ 
that most of wastewaters are dumped straight into rivers, lakes and estuaries without any treatment.

Figs. (3\& 4) shows the seasonal variations of bacterial load (TC \& $\mathrm{CF})$ at different stations of the lake, where the highest values recorded during summer then autumn and the lowest values during winter. This indicate that the increase in bacterial load associated with increased temperature was due to the increased degradation of organic matter and daring water in the Lake. the results agree with Mousa et al. (2018) who investigated that increasing fecal coli load in their study locations during hot seasons which may be attributed to pollution of water from these locations with municipal sewage.

Data presented by Whitman and Nevers (2008) also showed a positive relationship between coliform group counts and temperature and concluded that day was the most important component of variation for their data set, more so than beach location, depth, or time of day. Significant relationships between FCs and temperature were also reported by Frey $\boldsymbol{e t}$ al. (2013), Staley et al. (2013) and North et al. (2014).

Fish possess a diverse array of bacterial taxa, often reflecting the composition of the microflora of the surrounding water (Austin, 2002). Bacteria often occur in parts of fish on the body or internal organs of fish which indicate the extent of pollution of aquatic ecosystems (Salihu $\boldsymbol{e t}$ al., 2012; Ibemenuga and Okeke, 2014).

The results of bacterial indicators in the lake waters were done according to the European Commission (EC) Guide Standard (EC, 1998), which meet with the Egyptian Guide Standard (Ministry of Health, Egypt, 1996). They accept the guide values of the investigated bacteria up to 50 $\mathrm{CFU} / \mathrm{ml}$ of marine water for coliforms and $1 \mathrm{CFU} / \mathrm{ml}$ for fecal coliforms (E. coli). this is indicating that the present results of lake water bacterial load are exceed the permissible values mentioned by EC (1998) and Ministry of Health, Egypt (1996). Therefore, in order to prevent harmful bacteria from the fish environment, a lot of work should be done to reduce environment microbial load and to ensure that the water used is free from harmful bacteria.

As shown in Table (4) and Figures ( $3 \& 4$ ), the seasonal variation in bacteriological indictors of water lake samples revealed that the bacterial load of tilapia species tissues, where the highest bacterial load (TC\& CF) in muscle and skin of tilapia fish in Edku lake recoded at stations ( $3 \& 5)$ during summer and autumn seasons. These related to centering of these stations from drains mouths in the lake with increasing temperature and 
Farouk, A. / Egy. J. Aquac. 8 (2): 29-56(2018)
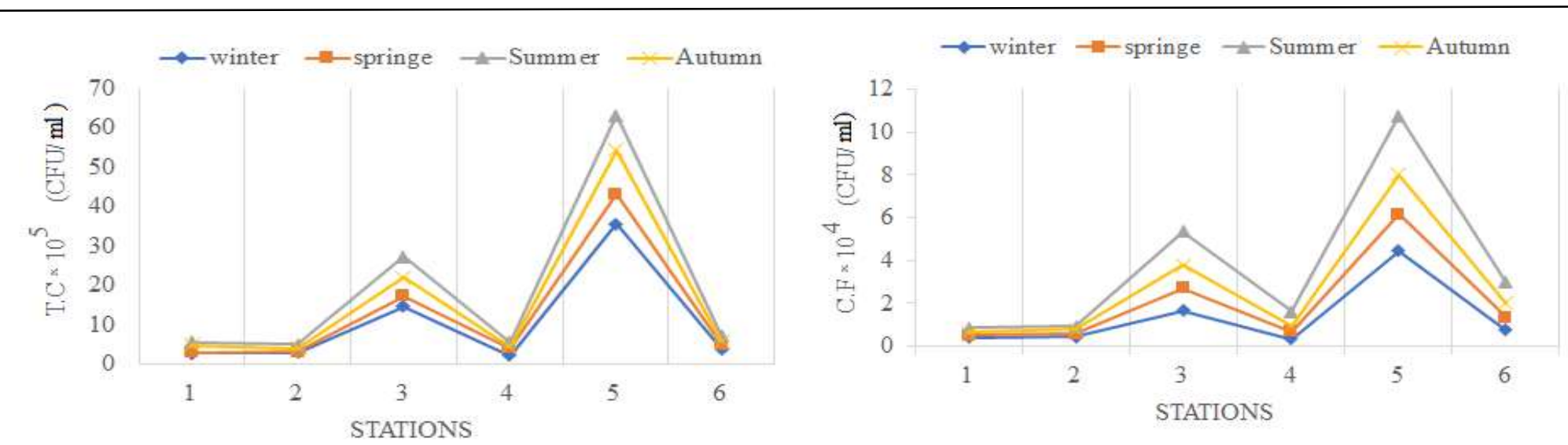

Fig. 3: Distribution of bacterial load (TC \& CF) in the lake water at the study stations
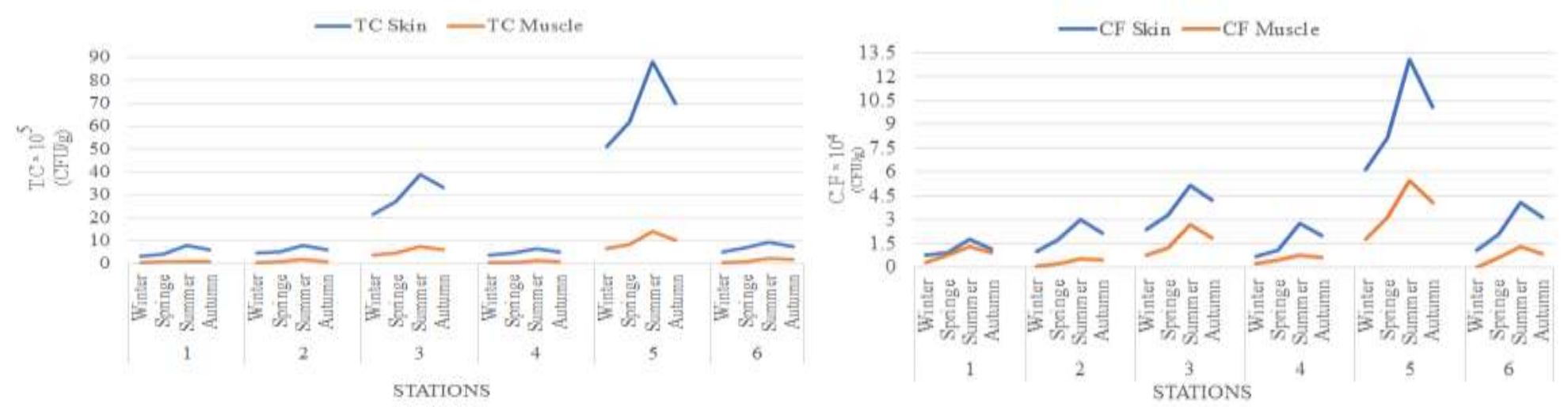

Fig. 4: Distribution of bacterial load (TC \& CF) in Tilapia tissues skin \&muscle) at the study stations 
decomposition, the results in the same trend with Anand et al. (2006) who stated that most of wastewaters are dumped straight into rivers, lakes and estuaries without any treatment. In addition to faecal coliforms in fish reflect the level of pollution of their environment, as the normal flora of fish do not include coliforms (Cohen \& Suvalm, 1973). In skin of tilapia, total bacterial count (TC) ranged between the highest numbers of $\left(88.18 \times 10^{5} \mathrm{CFU} / \mathrm{g}\right)$ and the lowest number of $\left(3.33 \times 10^{5} \mathrm{CFU} / \mathrm{g}\right)$. And coliform group $(\mathrm{CF})$ ranged between the highest numbers of $\left(13.07 \times 10^{4}\right.$ $\mathrm{CFU} / \mathrm{g})$ and the lowest number of $\left(0.74 \times 10^{4} \mathrm{CFU} / \mathrm{g}\right)$. While, Total bacterial count and coliform group in muscle of tilapia were $\left(14.04 \& 0.47 \times 10^{5}\right.$ $\mathrm{CFU} / \mathrm{g})$ and $\left(5.47 \& 0.31 \times 10^{4} \mathrm{CFU} / \mathrm{g}\right)$, respectively as shown in Fig., $\mathrm{s}()$. These results indicated that increasing bacterial load (TC \& CF) on skin than muscle of Tilapia species and this agree with Abdel-Hamid (2017) which This may be due to contact with the skin directly to the aquatic environment contaminated with bacteria with the possibility of skin friction increases the bacterial load. While, muscle has been considered by some to be sterile (Apun et al., 1999), whereas other investigators have reported the presence of bacteria (Evelyn and McDermott, 1961). Mandal et al. (2009) stated that highest density of coliform bacteria in water is responsible for higher density of these bacteria in fish body.

Manuals of food quality control. FAO indicated (FAO, 1979) stated that total bacteria count should less than $10^{5} / \mathrm{gm}$ and total coliforms should not exceed than 100/gm respectively. While, according to International Commission on the Microbiological Specification of Foods (ICMSF, 1982) indicated that acceptable limit of total bacterial counts and total coliform for white fish is $5 \times 10^{5}$ and $10 \mathrm{cfu} / \mathrm{g}$ respectively and E. coli should not be present. therefore, the bacterial loads found in this study for Nile tilapia organs (skin \& muscle) was beyond the standard value, which indicate their unacceptability as food from public health point of view which may be cause human health risk due to consumption of tilapia collected.

\section{Correlation Matrices}

Interrelations between the studied water parameters and bacterial load in Edku lake was carried out by correlation coefficient as tabulated in Table (5). Where, total bacterial count (TC) of the lake water had positive significantly $(\mathrm{P}<0.05)$ correlation with temperature and salinity where $(\mathrm{r}$ $=0.249$ and 0.297 , respectively), moreover it had positive significantly ( $\mathrm{P}$ $<0.01)$ correlation with $\mathrm{NH}_{4}, \mathrm{NO}_{2}, \mathrm{NO}_{3}, \mathrm{PO}_{4}^{-2}$ and $\mathrm{TP}$ where $(\mathrm{r}=0.865$, 
$0.583,0.925,0.329$ and 0.762 respectively). And it had negative significantly $(\mathrm{P}<0.01)$ correlation with chlorophyll "a" where $(\mathrm{r}=-0.322)$. Also, coliform group $(\mathrm{CF})$ of the lake water had positive significantly $(\mathrm{P}<$ 0.01 ) correlation with temperature, salinity, $\mathrm{NH}_{4}, \mathrm{NO}_{2}, \mathrm{NO}_{4}, \mathrm{PO}_{4}{ }^{-2}$ and $\mathrm{TP}$ where $(\mathrm{r}=0.397,0.357,0.633,0.890,0.361$ and 0.713 respectively). And it had negative significantly $(\mathrm{P}<0.01)$ correlation with dissolved oxygen where $(r=-0.322)$.

TC on tilapia skin had positive significantly $(\mathrm{P}<0.05)$ correlation with temperature, salinity and TDS where $(r=0.239,0.278$ and 0.268 respectively), moreover it had positive significantly $(\mathrm{P}<0.01)$ correlation with $\mathrm{NH}_{4}, \mathrm{NO}_{2}, \mathrm{NO}_{3}, \mathrm{PO}_{4}{ }^{-2}$ and TP where $(\mathrm{r}=0.854,0.851,0.940,0.347$ and 0.776 respectively). And it had negative significantly $(\mathrm{P}<0.05)$ correlation with chlorophyll "a" where $(\mathrm{r}=-0.301)$. While, TC on tilapia muscle had positive significantly $(\mathrm{P}<0.01)$ correlation with temperature, $\mathrm{NO}_{2}, \mathrm{NO}_{3}, \mathrm{PO}_{4}$ and $\mathrm{TP}$ where $(\mathrm{r}=0.314,0.529,0.944,0.395$ and 0.786 respectively). moreover, it had positive significantly $(\mathrm{P}<0.05)$ correlation with salinity, TDS and $\mathrm{NH}_{4}$ where $(\mathrm{r}=0.295,0.275$ and 0.824 respectively). And it had negative significantly $(\mathrm{P}<0.05)$ correlation with DO where $(r=-0.240)$.

$\mathrm{CF}$ on tilapia skin had positive significantly $(\mathrm{P}<0.01)$ correlation with temperature, salinity, TDS, $\mathrm{NH}_{4}, \mathrm{NO}_{2}, \mathrm{NO}_{3}, \mathrm{PO}_{4}{ }^{-2}$ and $\mathrm{TP}$ where $(\mathrm{r}=$ $0.422,0.356,0.340,0.924,0.657,0.865,0.329$ and 0.694 respectively). moreover, it had positive significantly $(\mathrm{P}<0.05)$ correlation with EC where $(\mathrm{r}=0.270)$. And it had negative significantly $(\mathrm{P}<0.05)$ correlation with DO and chlorophyll "a" where $(r=-0.297$ and -0.298 respectively). While, $\mathrm{CF}$ on tilapia muscle had positive significantly $(\mathrm{P}<0.01)$ correlation with temperature, salinity, $\mathrm{NH}_{4}, \mathrm{NO}_{2}, \mathrm{NO}_{3}$ and $\mathrm{TP}$ where $(\mathrm{r}=0.453,0.324$, $0.310,0.896,577$ and 0.784 respectively). moreover, it had positive significantly $(\mathrm{P}<0.05)$ correlation with $\mathrm{PO}_{4}^{-2}$ where $(\mathrm{r}=0.371)$. And it had negative significantly $(\mathrm{P}<0.05)$ correlation with $\mathrm{DO}$ where $(\mathrm{r}=-0.306$ respectively).

Generally, bacterial load had correlation coefficient with water quality parameters, which was positive correlation with temp., saln., Ec, TDS, $\mathrm{NH}_{4}, \mathrm{NO}_{2}, \mathrm{NO}_{3}, \mathrm{PO}_{4}{ }^{-2}$ and $\mathrm{Tp}$. And negative correlation with $\mathrm{pH}, \mathrm{DO}$ and T. Alk. Previous work on natural waters has shown relationships between indicator bacteria and environmental parameters. Water temperature is one of the most important environmental parameters affecting the concentrations of fecal indicator bacteria (Matsumoto and Omura, 1980). Some authors reported an inverse relationship between FC and water 
temperature, in contrast to other researchers, who found a direct relationship between FC and water temperature (Matsumoto and Omura, 1980\& Vaatanen, 1980). Simon and Makarewicz (2009) concluded that the summer peak observed in their bacterial indicators, Whitman and Nevers (2008) and North et al. (2014) also showed a positive relationship between E. coli counts and temperature and concluded that day was the most important component of variation for their data set and the significant relationships between FCs and temperature was also reported by both Frey et al. (2013) and Staley et al. (2013).

The absence of favorable environmental conditions and the decreased values of salinity are the main factors affecting the presence of aquatic fauna in the lake (Shaltout and Al-Sodany, 2008). Where, Mousa et al. (2018) mentioned that water salinity decreasing that is being the main factor that leads to the diversion of the microbial communities. Spietz $\boldsymbol{e t}$ al. (2015) found a strong negative association between bacterial richness and dissolved oxygen. The results that showed the influence of $\mathrm{pH}$ on the survival fecal coli (FC) was inconsistent (Jamieson et al., 2002 and Neger, 2002). $\mathrm{FC}$ bacteria have greater survival in neutral environments in the $\mathrm{pH}$ range of 6 to 7, where the survival rate of coliform (fecal coli) in acidic environment was $7.5 \%$ and in alkaline environment was $66.11 \%$ (Wahyuni, 2015). Abdel-Hamid (2017) suggested that DO decreasing was suitable for coliform group which consider facultative anaerobic bacteria. Also, decrease in $\mathrm{NO}_{2}, \mathrm{NO}_{3}$ and $\mathrm{TN}$ explained the nutrient consumed by bacteria and other aquatic life. A comparison of the nutrient levels in different also reveal that the TC was high when the nutrient levels were also high. Sugumar and Anandharaj (2016) revealed positive correlation between TBC and nutrients like phosphates. In the same trend Romero (1999) indicated that concentrations of FC are coincident with the increased phosphorus and nitrogen concentrations of lake water.

\section{Conclusion}

The study recommends that the need to treat the drainage of the lake to reduce the harmful bacterial load in the lake, which is detrimental to the health of fish and human consumption. also recommends to cleanse Boughaz and work on the establishment of radial channels from the Boughaz to many of the sites of the lake to increase the water exchange between the lake and the sea, as well as the disinfection from aquatic plants and benthic plankton for restoring the lake to the ecological balance. 
Farouk, A. / Egy. J. Aquac. 8 (2): 29-56(2018)

Table 5: Pearson's correlation coefficients among the water parameters and bacterial load of Edku lake during four seasons of the study.

\begin{tabular}{|c|c|c|c|c|c|c|c|c|c|c|c|c|c|c|c|c|c|c|c|c|}
\hline & & temp & $\mathrm{pH}$ & Saln. & EC & TDS & $\mathrm{NH}_{4}$ & $\mathrm{NO}_{2}$ & $\mathrm{NO}_{3}$ & $\mathrm{PO}_{4}^{-2}$ & DO & Chlor & $\mathrm{TP}$ & $\begin{array}{l}\text { T. } \\
\text { Alk. }\end{array}$ & $\begin{array}{c}\text { TC } \\
\text { Water } \\
\end{array}$ & $\begin{array}{c}\mathrm{CF} \\
\text { water }\end{array}$ & $\begin{array}{c}\text { TC } \\
\text { Skin } \\
\end{array}$ & \begin{tabular}{|c|} 
TC \\
Muscle \\
\end{tabular} & $\begin{array}{c}\text { CF } \\
\text { Skin } \\
\end{array}$ & $\begin{array}{c}\mathrm{CF} \\
\text { Muscle } \\
\end{array}$ \\
\hline Temp & $\begin{array}{c}\text { Pearson Correlation } \\
\text { Sig. (2-tailed) } \\
\end{array}$ & 1 & & & & & & & & & & & & & & & & & & \\
\hline $\mathrm{pH}$ & \begin{tabular}{|l|} 
Pearson Correlation \\
Sig. (2-tailed)
\end{tabular} & $\begin{array}{l}.598^{* *} \\
.000\end{array}$ & 1 & & & & & & & & & & & & & & & & & \\
\hline Saln. & $\begin{array}{c}\text { Pearson Correlation } \\
\text { Sig. (2-tailed) }\end{array}$ & $\begin{array}{l}428^{* *} \\
.000\end{array}$ & $\begin{array}{l}.116 \\
.330\end{array}$ & 1 & & & & & & & & & & & & & & & & \\
\hline EC & \begin{tabular}{|c|} 
Pearson \\
Correlation \\
Sig. (2-tailed) \\
\end{tabular} & $\begin{array}{l}.303^{* *} \\
.010\end{array}$ & $\begin{array}{l}.239^{*} \\
043\end{array}$ & $\begin{array}{l}.866^{* *} \\
.000\end{array}$ & 1 & & & & & & & & & & & & & & & \\
\hline TDS & $\begin{array}{l}\text { Pearson } \\
\text { Correlation } \\
\text { Sig. (2-tailed) } \\
\end{array}$ & $\begin{array}{l}.380^{* *} \\
.001\end{array}$ & $\begin{array}{l}.090 \\
.452\end{array}$ & $\begin{array}{l}.945^{* *} \\
.000\end{array}$ & \begin{tabular}{|c|}
$.858^{* *}$ \\
.000
\end{tabular} & 1 & & & & & & & & & & & & & & \\
\hline $\mathrm{NH}_{4}$ & $\begin{array}{l}\text { Pearson } \\
\text { Correlation } \\
\text { Sig. (2-tailed) } \\
\end{array}$ & $\begin{array}{l}344^{* *} \\
.003\end{array}$ & $\begin{array}{r}-.027- \\
.823\end{array}$ & $\begin{array}{l}.149 \\
.211\end{array}$ & $\begin{array}{c}.14 \\
5 \\
.223 \\
\end{array}$ & $\begin{array}{l}.149 \\
.213\end{array}$ & 1 & & & & & & & & & & & & & \\
\hline $\mathrm{NO}_{2}$ & $\begin{array}{c}\text { Pearson } \\
\text { Correlation } \\
\text { Sig. (2-tailed) }\end{array}$ & $\begin{array}{l}.228 \\
.054\end{array}$ & $\begin{array}{l}.020 \\
.867\end{array}$ & $\begin{array}{r}-.187- \\
.117\end{array}$ & \begin{tabular}{|r|}
$.107-$ \\
.369
\end{tabular} & $\begin{array}{l}-.203- \\
.087\end{array}$ & $\begin{array}{l}.774^{* *} \\
.000\end{array}$ & 1 & & & & & & & & & & & & \\
\hline $\mathrm{NO}_{3}$ & $\begin{array}{c}\text { Pearson } \\
\text { Correlation } \\
\text { Sig. (2-tailed) } \\
\end{array}$ & $\begin{array}{l}.185 \\
.119\end{array}$ & $\begin{array}{l}-.296-^{*} \\
.012\end{array}$ & $\begin{array}{l}.148 \\
.214\end{array}$ & \begin{tabular}{|l|}
$.027-$ \\
.825 \\
\end{tabular} & $\begin{array}{l}.135 \\
.258\end{array}$ & $\begin{array}{l}.754^{* *} \\
.000\end{array}$ & $\begin{array}{l}.618^{* *} \\
.000\end{array}$ & 1 & & & & & & & & & & & \\
\hline $\mathrm{PO}_{4}^{-2}$ & $\begin{array}{l}\text { Pearson Correlation } \\
\text { Sig. (2-tailed) }\end{array}$ & $\begin{array}{l}.221 \\
.062\end{array}$ & $\begin{array}{l}.002 \\
.988\end{array}$ & $\begin{array}{l}-.522-^{* *} \\
.000\end{array}$ & \begin{tabular}{|c|}
$.641-$ \\
$* *$ \\
.000 \\
\end{tabular} & $\begin{array}{l}-.542-^{* *} \\
.000\end{array}$ & $\begin{array}{l}.390^{* *} \\
.001\end{array}$ & $\begin{array}{l}.644^{* *} \\
.000\end{array}$ & $\begin{array}{r}.523^{* *} \\
.000\end{array}$ & 1 & & & & & & & & & & \\
\hline DO & $\begin{array}{c}\text { Pearson } \\
\text { Correlation } \\
\text { Sig. (2-tailed) }\end{array}$ & $\begin{array}{l}-.829-^{* *} \\
.000\end{array}$ & $\begin{array}{l}-.497-^{* *} \\
.000\end{array}$ & $\begin{array}{c}-.713-^{* *} \\
.000\end{array}$ & \begin{tabular}{|c|}
$-.626-$ \\
$* *$ \\
.000 \\
\end{tabular} & $\begin{array}{l}-.6511^{* *} \\
.000\end{array}$ & $\begin{array}{c}-.120- \\
.314\end{array}$ & $\begin{array}{r}-.005 \\
.967\end{array}$ & $\begin{array}{c}-.093- \\
.439\end{array}$ & $\begin{array}{l}.083 \\
.488\end{array}$ & 1 & & & & & & & & & \\
\hline Chlor. & \begin{tabular}{|c|} 
Pearson Correlation \\
Sig. (2-tailed)
\end{tabular} & $\begin{array}{l}.404^{* * *} \\
.000 \\
\end{array}$ & $\begin{array}{l}.210 \\
.077 \\
\end{array}$ & $\begin{array}{l}.023 \\
.845 \\
\end{array}$ & \begin{tabular}{|r|}
$.138-$ \\
.248 \\
\end{tabular} & $\begin{array}{c}-.012- \\
.922 \\
\end{array}$ & $\begin{array}{l}-.4655^{* *} \\
.000 \\
\end{array}$ & $\begin{array}{l}-.331- \\
* .005 \\
* .005 \\
\end{array}$ & $\begin{array}{c}-.161- \\
.175 \\
\end{array}$ & $\begin{array}{l}.194 \\
.102 \\
\end{array}$ & $\begin{array}{l}-.473- \\
{ }^{* *} .000 \\
\end{array}$ & 1 & & & & & & & & \\
\hline
\end{tabular}


Farouk, A. / Egy. J. Aquac. 8 (2): 29-56(2018)

\begin{tabular}{|c|c|c|c|c|c|c|c|c|c|c|c|c|c|c|c|c|c|c|c|c|}
\hline $\mathrm{TP}$ & \begin{tabular}{|c|} 
Pearson \\
Correlation \\
Sig. (2- \\
tailed) \\
\end{tabular} & $\begin{array}{c}.294 \\
* \\
.012\end{array}$ & $\begin{array}{c}-.086- \\
.472\end{array}$ & $\begin{array}{r}.016 \\
.894\end{array}$ & $\begin{array}{l}-.195- \\
.101\end{array}$ & $\begin{array}{l}.040 \\
.737\end{array}$ & $\begin{array}{c}.562^{\text {*** }} \\
.000\end{array}$ & \begin{tabular}{|l}
$.364^{* *}$ \\
.002
\end{tabular} & $\begin{array}{c}.762^{\text {*** }} \\
.000\end{array}$ & $\begin{array}{l}449^{* *} \\
.000\end{array}$ & $\begin{array}{c}-.061- \\
.611\end{array}$ & $\begin{array}{l}.050 \\
.677\end{array}$ & 1 & & & & & & & \\
\hline T.ALK. & \begin{tabular}{|c|} 
Pearson \\
Correlation \\
Sig. (2- \\
tailed) \\
\end{tabular} & $\begin{array}{c}- \\
.181 \\
- \\
.129 \\
\end{array}$ & $\begin{array}{c}-.065- \\
.590\end{array}$ & $\begin{array}{l}-.295- \\
* \\
.012\end{array}$ & \begin{tabular}{|c|}
$-.238-^{*}$ \\
.044
\end{tabular} & $\begin{array}{l}-.321- \\
* * \\
.006\end{array}$ & $\begin{array}{l}-.081- \\
.497\end{array}$ & $\begin{array}{c}- \\
.143- \\
.230\end{array}$ & $\begin{array}{c}- \\
.121 \\
- \\
.310 \\
\end{array}$ & $\begin{array}{c}- \\
.048 \\
.690\end{array}$ & $\begin{array}{l}.257^{*} \\
.029\end{array}$ & $\begin{array}{c}-.084- \\
.480\end{array}$ & $\begin{array}{l}-.043 \\
.718\end{array}$ & 1 & & & & & & \\
\hline $\begin{array}{c}\text { TC } \\
\text { Water }\end{array}$ & \begin{tabular}{|c|} 
Pearson \\
Correlation \\
Sig. (2- \\
tailed) \\
\end{tabular} & $\begin{array}{c}.249 \\
* \\
.035\end{array}$ & $\begin{array}{r}-.175- \\
.140\end{array}$ & $\begin{array}{l}.297^{*} \\
.011\end{array}$ & $\begin{array}{l}.169 \\
.155\end{array}$ & $\begin{array}{l}.287^{*} \\
.015\end{array}$ & $\begin{array}{c}.865^{\text {*** }} \\
.000\end{array}$ & $\begin{array}{l}.583^{* *} \\
.000\end{array}$ & $\begin{array}{c}.925^{\text {*** }} \\
.000\end{array}$ & $\begin{array}{c}.329^{*} \\
* \\
.005\end{array}$ & $\begin{array}{l}-.148- \\
.215\end{array}$ & $\begin{array}{c}-.322-^{*} \\
.006\end{array}$ & $\begin{array}{l}.762^{* * 1} \\
.000\end{array}$ & $\begin{array}{c}-.083- \\
.489\end{array}$ & 1 & & & & & \\
\hline $\begin{array}{c}\mathrm{CF} \\
\text { Water }\end{array}$ & \begin{tabular}{|c|} 
Pearson \\
Correlation \\
Sig. (2- \\
tailed) \\
\end{tabular} & $\begin{array}{l}.397 \\
* * \\
.001\end{array}$ & $\begin{array}{l}-.029- \\
.806\end{array}$ & $\begin{array}{l}.357^{* *} \\
.002\end{array}$ & $\begin{array}{l}.245^{*} \\
.038\end{array}$ & $\begin{array}{l}.333^{* *} \\
.004\end{array}$ & $\begin{array}{c}.869^{\text {*** }} \\
.000\end{array}$ & $\begin{array}{r}.633^{* *} \\
.000\end{array}$ & $\begin{array}{l}890^{* * *} \\
.000\end{array}$ & $\begin{array}{c}.361^{*} \\
* \\
.002\end{array}$ & $\begin{array}{c}-.308-^{*} \\
.009\end{array}$ & $\begin{array}{c}-.255-^{*} \\
.031\end{array}$ & $\begin{array}{l}.713^{* * 1} \\
.000\end{array}$ & $\begin{array}{l}- \\
.11 \\
4- \\
.340\end{array}$ & $\begin{array}{l}.972^{* *} \\
.000\end{array}$ & 1 & & & & \\
\hline $\begin{array}{c}\text { TC } \\
\text { Skin }\end{array}$ & \begin{tabular}{|c|} 
Pearson \\
Correlation \\
Sig. (2- \\
tailed) \\
\end{tabular} & $\begin{array}{l}.239 \\
* \\
.044\end{array}$ & $\begin{array}{c}-.201- \\
.091\end{array}$ & $\begin{array}{l}.278^{*} \\
.018\end{array}$ & $\begin{array}{l}.143 \\
.229\end{array}$ & $\begin{array}{l}.268^{*} \\
.023\end{array}$ & $\begin{array}{l}854^{* *} \\
.000\end{array}$ & $\begin{array}{c}581 * * \\
.000\end{array}$ & $\begin{array}{c}.940 * \\
* \\
.000\end{array}$ & $\begin{array}{l}.347^{* * *} \\
.003\end{array}$ & $\begin{array}{c}- \\
.138 \\
- \\
.247 \\
\end{array}$ & $\begin{array}{c}-.301-^{*} \\
.010\end{array}$ & $\begin{array}{c}.776^{\text {*in }} \\
.000\end{array}$ & $\begin{array}{c}-.063- \\
.596\end{array}$ & $\begin{array}{c}.997^{*} \\
* \\
.000\end{array}$ & $\begin{array}{l}.968^{\text {*** }} \\
.000\end{array}$ & 1 & & & \\
\hline $\begin{array}{c}\text { TC } \\
\text { Muscle }\end{array}$ & \begin{tabular}{|c|} 
Pearson \\
Correlatio \\
$\mathrm{n}$ \\
Sig. (2- \\
tailed) \\
\end{tabular} & $\begin{array}{l}.314^{* * *} \\
.007\end{array}$ & $\begin{array}{c}- \\
.148- \\
.214\end{array}$ & $\begin{array}{l}.295^{*} \\
.012\end{array}$ & $\begin{array}{l}.159 \\
.182\end{array}$ & $\begin{array}{l}.275^{*} \\
.019\end{array}$ & $\begin{array}{l}.824^{\text {** }} \\
.000\end{array}$ & $\begin{array}{l}.529^{* *} \\
.000\end{array}$ & $\begin{array}{l}.944 \\
* * \\
.000\end{array}$ & $\begin{array}{l}395^{* *} \\
.001\end{array}$ & $\begin{array}{l}.240-^{*} \\
.024\end{array}$ & $\begin{array}{c}-.188- \\
.114\end{array}$ & $\begin{array}{c}.786^{*} \\
* \\
.000\end{array}$ & $\begin{array}{c}-.090- \\
.450\end{array}$ & $\begin{array}{r}-.980^{*} \\
.000\end{array}$ & $\begin{array}{l}.974^{* *} \\
.000\end{array}$ & $\begin{array}{r}.985^{* *} \\
.000\end{array}$ & 1 & & \\
\hline $\begin{array}{l}\text { CF } \\
\text { Skin }\end{array}$ & \begin{tabular}{|c|} 
Pearson \\
Correlation \\
Sig. (2- \\
ailed) \\
\end{tabular} & $\begin{array}{l}.422 \\
* * \\
.000\end{array}$ & $\begin{array}{r}-.028- \\
.816\end{array}$ & $\begin{array}{c}.356^{*} \\
* \\
.002\end{array}$ & $.270^{*}$ & $\begin{array}{l}.340^{* *} \\
.004\end{array}$ & $\begin{array}{c}.924^{* * *} \\
.000\end{array}$ & $\begin{array}{l}.657^{* * *} \\
.000\end{array}$ & $\begin{array}{c}.865 \\
* * \\
.000\end{array}$ & $\begin{array}{l}329^{* *} \\
.005\end{array}$ & \begin{tabular}{|c}
$.297-^{*}$ \\
.011
\end{tabular} & $\begin{array}{c}-.298-^{*} \\
.011\end{array}$ & $\begin{array}{c}.694^{*} \\
* \\
.000\end{array}$ & $\begin{array}{c}-.118- \\
.331\end{array}$ & $\begin{array}{c}.965^{*} \\
* \\
.000\end{array}$ & $\begin{array}{l}.981^{* *} \\
.000\end{array}$ & $\begin{array}{c}.959^{* *} \\
.000\end{array}$ & $\begin{array}{c}.956^{* *} \\
.000\end{array}$ & 1 & \\
\hline $\begin{array}{c}\text { CF } \\
\text { Muscle }\end{array}$ & \begin{tabular}{|c|} 
Pearson \\
Correlation \\
Sig. (2- \\
tailed) \\
\end{tabular} & $\begin{array}{l}.453^{* *} \\
.000\end{array}$ & $\begin{array}{l}.043 \\
.722\end{array}$ & $\begin{array}{c}.324^{*} \\
* \\
.005\end{array}$ & $\begin{array}{l}.193 \\
.105\end{array}$ & $\begin{array}{l}.310^{* *} \\
.008\end{array}$ & $\begin{array}{l}.846^{\text {** }} \\
.000\end{array}$ & $\begin{array}{l}.577^{* *} \\
.000\end{array}$ & $\begin{array}{l}.857 \\
* * \\
.000\end{array}$ & $\begin{array}{l}371^{\text {** }} \\
.001\end{array}$ & $\begin{array}{l}.306^{-* *} \\
.009\end{array}$ & $\begin{array}{r}-.211- \\
.076\end{array}$ & $\begin{array}{c}.784^{*} \\
* \\
.000\end{array}$ & $\begin{array}{c}-.125- \\
.296\end{array}$ & $\begin{array}{c}.957^{*} \\
* \\
.000\end{array}$ & $\begin{array}{c}.979^{* *} \\
.000\end{array}$ & $\begin{array}{l}.950^{* * *} \\
.000\end{array}$ & $\begin{array}{c}.956^{* *} \\
.000\end{array}$ & $\begin{array}{c}.962^{* * *} \\
.000\end{array}$ & 1 \\
\hline
\end{tabular}

**. Correlation is significant at the 0.01 level (2-tailed). * *. Correlation is significant at the 0.05 level (2-tailed). 


\section{REFERENCES}

Abdel-Hamid, E.A.A. (2017). Assessment of water quality and Bacterial Contamination in Water, Sediments and Fish of Lake Manzala. Egy. J. Aquac., 7 (1):55-75.

Abel, P.D. (1998). Water pollution biology. Second edition. Printed in Great Britain by T.J. international Ltd. London. Abo-Donia, M.A. (1990): Specified deviced techniques for detecting fish contaminate. Ph.D. thesis. In food technology, faculty of Agriculture Ain Shams University.

Abu Khatit, A.M; Shaker, I.M. and Shetaia, S.A. (2017). Water quality assessment and potential health risk of Manzala Lake- Egypt. Al Azhar Bulletin of Science, 9th.: 119-136.

American Puplic Health Assocition (APHA) (1995). Standard Methods for the Examination of Water and Waste, American Public Health Association. New York, 1193 pp.

American Puplic Health Assocition (APHA) (2000). Standard Methods for the Examination of Water and Wastewater (16th Ed.). Washington, D.C.

Anand, C.; Akolkar, P. and Chakrabarti, R. (2006). Bacteriological water quality Status of river Yamuna in Delhi. J. Environ. Biol., 27: 97-101.

Apun, K.; Yusof, A.M., and Jugang, K. (1999). Distribution of bacteria in tropical freshwater fish and ponds. Int. J. Environ. Health Res., 9: 285-292.

Austin, B. (2002). The bacterial microflora of fish. The scientific world journal, 2: 558-572.

Badr, N.B. and Hussein, M.M. (2010). An input/output flux model of total phosphorus in Lake Edku, a northern eutrophic Nile Delta Lake, Global J. Environ. Res., 4 (2): 64-75.

Barica, J. and Mathias, J.A. (1979). Oxygen depletion and winterkill risk in small prairie lakes under extended ice cover. J. Fish. Res. Board Can., (36): 980-986.

Barker, D.; Allan, G. L.; Rowland, S. J.; Kennedy, J. D. and Pickles, J. M. (2009). A Guide to Acceptable Procedures and Practices for Aquaculture and Fisheries Research. 3rd Edition. Primary Industries (Fisheries) ACEC. Nelson Bay, Australia.

Begum, A.; Amin, M.d.; Kaneco, A. and Ohta, K. (2005). Selected elemental composition of the muscle tissue of three species of fish, Tilapia nilotica, Cirrhina mrigala and Clarias batrachus, from the fresh water Dhanmondi Lake in Bangladesh. Food. Chem., 93: 439443. 
Bird Life International (2008). Bird Life's online World Bird Database: the site for bird conservation. Version 2.1, Cambridge, UK: Bird Life International. Available online at: http://www.birdlife.org (last accessed30/6/2008).

Boyd, C.E. and Tucker, C.S. (1998). Pond Aquaculture Water Quality Management. Kluwer Academic Publishers, Boston, Massachusettes, $700 \mathrm{pp}$.

Chervinski, J. (1982). Environmental physiology of tilapias. In: The Biology and Culture of Tilapias, ICLARM Conference Proceedings, Manila, Philippines, (7): 119-128.

Cohen, J. and Shuval, H.I. (1973). Coliforms, fecal coliform and fecal streptococci as indicators of water pollution. Water Soil Pollution, 2: 85-95.

Darwish, S.I. (2016). Water quality and heavy metals pollution in soil, water and fish in Lake Burullus, Ph.D. Thesis. Fac. of Agriculture. Univ. of Saba Basha (Alex.). Dep. of fish production.

Duncan, D.B. (1955). Multiple range and multiple F-test. Biomet., 11: 115.

Dytham, C. (1999). Choosing and Using Statistics: A Biologist s Guide. Blackwell Science Ltd., London, UK.

El morshedy, E.M. (2017). Effect of pollution on water quality, soil and fish performance in lakes and farm ponds. Ph.D. Thesis. Fac. of Agriculture. Univ. of Saba Basha (Alex.). Dep. of fish production.

El-Sherif, Z.M. and Mahmoud Th.H. (1991). The effect of anionicdetergents on the standing cropof phytoplankton in El-Mex Bay, Egypt. The Bulletin of the High Institute of Public Health, XXI (3): 631-8.

European Commission (EC) (1998). Quality of Bathing Water; Document EUR 18166, European Commission, Brussels.

Evelyn, T.P. and McDermott, L.A. (1961). Bacteriological studies of freshwater fish. 1. Isolation of aerobic bacteria from several species of Ontario fish. Can. J. Microbiol., 7: 357-382.

Farouk, A. (2009). Some studies on water pollution of Manzala Lake by heavy metals and others and effect of these on stock assessment of fish. M.Sc. Thesis. Faculty of Science. Al-Azhar University.

Food and Agriculture Organization of the united states (FAO) (1979). Manuals of Food Quality Control. FAO Food and Nutrition paper $14 / 4$.

French, T.D. and Petticrew, E.L. (2007). Chlorophyll $a$ seasonality in four shallow eutrophic lakes (northern British Columbia, Canada) and the critical roles of internal phosphorus loading and temperature Hydrobiologia, 575: 285-299. 
Frey, S.K.; Topp, E.; Edge, T.A.; Fall, C.; Gannon, V.P.J. and Jokinen, C.C.; et al. (2013). Using SWAT, Bacteroidales microbial source tracking markers, and fecal indicator bacteria to predict waterborne pathogen occurrence in an agricultural watershed. Water Res. 47: 6326-6337.

Ibemenuga, K.N. and Okeke, T.E. (2014). Bacteriological quality of freshwater fish caught from two natural lakes in the rainforest region of south-eastern Nigeria. Animal Research International, 11(2): 1946 $-1952$.

International Commission on the Microbiological Specification of Foods (ICMSF) (1982). Microorganisms in food. Vol. 2, Sampling for microbiological analysis:principles and specific applications. Univ. Toronto Press, Toronto, Canada.

Jamieson, R.C.; Gordon, R.J.; Sharples, K.E.; Stratton, G.W. and Madani, A. (2002). Movement and persistence of fecal bacteria in agricultural soils and subsurface drainage waters: A review. Canadian Biosystems Engineering, 44: 1.1-1.9.

Khalil, M.T.; Shakir, S.H.; Saad, A.A.; El Shabrawy, G.M. and Hassan, M.M. (2008). Physico-chemical environment of Lake Edku, Egypt. Egypt. J. Aquat. Biol. Fish., 12(2): 119-132.

Leung, C. and Huang Y. and Pancorbo, O. (1992). Bacterial pathogens and indicators in catfish and pond environments. Journal of Food Protection, 55: 424-427.

Mainston, C.P. and Parr, W. (2002). Phosphorus in rivers-ecology and management. Science of the Total Environment, 282-283: 25-47.

Mandal, S.C.; Hasan, M.; Rahman, M.Sh.; Manik, M.H.; Mahmud, Z.H. and Islam, MD.S. (2009). Coliform Bacteria in Nile Tilapia, Oreochromis niloticus of Shrimp-Gher, Pond and Fish Market. World Journal of Fish and Marine Sciences, 1(3): 160-166.

Masoud, M.S.; Mahmoud, ThH. and Abdel-Halim, A.M. (2001). Chemical studies of El-Mex Bay, Alexandria. Proceeding of the Second Conference and Exhibition for Life and Environment, 3-5 April, Alexandria, pp. 339-60.

Matsumoto, J and Omura, I. (1980). Some factors affecting the survival of fecal indicator bacteria in sea water. Technology Reports, Tohokw University, 45(2).

Ministry of Health Egypt (1996). Microbiological Standards of the Egyptian Recreational Waters. Report (64).

Moufaddal, W.; El-Sayed, E. and Deghady, E. (2008). Updating morphometric and edaphic information of lakes Edku and Burullus, Northern Egypt, with the aid of satellite remote sensing, Egypt. J. Aquat. Res., 34 (4): 291-310. 
Mousa, I.E.; Emara, I.K.; Farfour, S.A. and Eldourghamy, A.S. (2018). Microbial profile and its changing rates of Lake Burullus, Egypt as wastewater receiving body. Water and Environment Journal, 32: 67-74.

Neger, M.K. (2002). Literature Review on the Survival of Fecal Coliform in Fresh and Saline Waters, and Sediments. Lummi Indian Business Council, Funded By: Environment Protection Agency (Agreement No. GA-97020501-0).

North, R.L.; Khan, N.H.; Ahsan, M.; Prestie, C.; Korber, D.R.; Lawrence, J.R. and Hudson, J.J. (2014). Relationship between water quality parameters and bacterial indicators in a large prairie reservoir: Lake Diefenbaker, Saskatchewan, Canada. Can. J. Microbiol., 60: 243-249.

Okbah, M.A. and El-Gohary, S.E. (2002). Physical and chemical characteristics of Lake Edku water, Egypt. Mediterranean Marine Science, 31: 27-39.

Okbah, M.A.; Abd El-Halim, A.M.; Abu El-Regal, M.A. and El. Nassar, M. (2017). Water Quality Assessment of Lake Edku using physicochemical and Nutrients Salts, Egypt. Chemistry Research Journal, 2(4):104-117.

Ouyang, L.L.; Pan, Y.D.; Huang, C.M.; TANG, Y.; DU, J. and XIAO, W. (2016). Water quality assessment of benthic diatom communities for water quality in the subalpine karstic lakes of Jiuzhaigou, a world heritage site in China. Journal of Mountain Science, 13(9): 1632-1644.

Pal, M.; Samal, N.R.; Roy, P.K. and Roy, M.B. (2015). Electrical Conductivity of Lake Water as Environmental Monitoring - A Case Study of Rudrasagar Lake. IOSR Journal of Environmental Science, Toxicology and Food Technology, 9: 66-71.

Pooja Devi, A.B. (2013). Water quality guidelines for the management of pond fish culture. International Journal of Environmental Science, 3 (6): 1980-2009.

Pullela, S.; Fernandes, C.F.; Flick, G.J.; Libey, G.S.; Smith, S.A. and Coale, C.W. (1998). Indicative and pathogenic microbiological quality of aquacultured finfish grown in different production systems. J. Food Prot. 61: 205-210.

Ramakrishnaiah, C.R.; Sadashivaiah, C. and Ranganna, G. (2009). Assessment of water quality index for the groundwater in Tumkur Taluk, Karnataka State India., CODEN ECJHAOE-Journal of Chemistry, 6(2): 523530.

Ramos, M. and Lyon, W.J. (2000). Reduction of endogenous bacteria associated with catfish fillets using the grovac process. Journal of Food Protection, 63: 1231-1239. 
Randall, D.J. and Tsui, T.K. (2002). Ammonia Toxicity in Fish. Marine Pollution Bulletin, 45:17-23.

Romero, J.R. (1999). Imberger J. Lake Pamvotis Project, Final Report. Western Australia: CWR.

Saad, M.A. (2003). Impact of diffuse pollution on the socio-economic development opportunities in the coastal Nile delta lakes. Diffuse Pollution Conference Dublin 2003 ECSA, 5: 6-81.

Saeed, S.M. (2013). Impact of environmental parameters on fish condition and quality in Lake Edku, Egypt. Egypt. J. Aquat. Biol. \& Fish., 17(1): 101-112.

Salihu, M.D.; Junaidu, A.U.; Magaji, A. A.; Falekle, O.O.; Yusuf, Y.; Abubakar, M.B.; Tambuwal, F.M. and Samaila, S. (2012). Bacteriological quality of freshwater fishes caught from Sokoto River, Sokoto, Nigeria. Journal of Veterinary Advances, 2(1): 65- 69.

Schlotfeldt, H.J. and Alderman, D.J. (1995). What should I do? A practical guide for the fresh water fish farmer. European Association of Fish Pathologists, Dorset UK.

Sendecor, and Cochran, W.G. (1982). Statistical methods 6th. Edition Iowa State Univ. Press. Amer. IA- USA- 593.

Shaker, I.M. (2006). Water hyacinth as a biological treatment for sewage wastewater in aquaculture earthen ponds. Egyptian Journal of Aquatic Biology and Fisheries, 10:1-20.

Shaker, I.M. (2008). Effect of using different types of organic manure (compost; chicken, Mycelium) and mineral fertilizer on water quality, plankton abundance and on growth performance of Oreochromis niloticus in earthen ponds. Abbassa Int. J. Aqua. , 4(1): 203-226.

Shakweer, L.M. (2005). Ecological and Fisheries Development of LAKE Manzalah (Egypt), I- Hydrography and Chemistry of Lake Manzalah, Egypt. J. of Aquacult., 31(1): 251-270.

Shaltout, K.H. and Al-Sodany, Y.M. (2008). Vegetation Analysis of Burullus Wetland: A Ramsar Site in Egypt. Wetl. Ecol. Manag., 16: 421-439.

Shewan, J.M. and Hopps, G. (1967). The bacteriology of fish spoilage and preservation. Progress in industries Microbiology (ed. By D.J.D. Hockenhull). Illfe Books, London.

Simon, R.D. and Makarewicz, J.C. (2009). Impacts of manure management practices on stream microbial loading into Conesus Lake, NY. J. Great Lakes Res., 35: 66-75.

Spietz1, R.L.; Williams, C.M.; Rocap, G. and Horner-Devine, M.C. (2015). A Dissolved Oxygen Threshold for Shifts in Bacterial Community Structure in a Seasonally Hypoxic Estuary. PLoS One. Journal pone, 10(8). 
Staley, Z.R.; Chase, E.; Mitraki, C.; Crisman, T.L. and Harwood, V.J. (2013). Microbial water quality in freshwater lakes with different land use. J. Appl. Microbiol., 115(5): 1240-1250.

Sugita, H.; Tsunohara, M.; Ohkoshi, T. and Deguchi, Y. (1988). The establishment of an intestinal microflora in developing goldfish (Carassius auratus) of culture ponds. Microbial Ecology, 15: 333-344.

Sugumar, R. and Anandharaj, B. (2016). Assessment of Bacterial Load in the Fresh Water Lake System of Tamil Nadu. Int. J. Curr. Microbiol. App. Sci., 5(6): 236-246.

Vaatanen, P. (1980). Factor Analysis of the import of the environment on microbial communities in the Tvarminne area, southern coast of Finland. Applied Environmental Microbiology, 40(1): 55-61.

Wahyuni, E.A. (2015). The Influence of $\mathrm{pH}$ Characteristics on The Occurrence of Coliform Bacteria in Madura Strait. Procedia Environmental Sciences, 23: 130-135.

Whitman, R.L. and Nevers, M.B. (2008). Summer E. coli patterns and responses along 23 Chicago beaches. Environ. Sci. Technol., 42(24): 9217-9224.

Zaghloul, F.A.; Tadros, A.B.; Okbah, M.A. and Asaad, F.N. (2005). Phytoplankton Standing Crop of El-max Fish Farm in Relation to the Environmental Conditions. Egyptian Journal of Aquatic Research, 31: 157-178.

Zhou, W.H.; Yuan, X.C., Huo, W.Y. and Yin, K.D. (2004). Distribution of chlorophyll a and primary productivity in the adjacent sea area of Changjiang River Estuary. Acta Oceanologica Sinica, 26(3):143-150. 


\section{جودة المياة و الحمل البكتيري في المياة و أنسجة أسماك البلطي في بحيرة أدكو \\ علم الاين فاروق أحمد}

قسم الليمنولوجي- المعمل المركزى لبحوث الثروة السمكية

العبأسةــ ابو حمادـ شرقيةــ مصر لبر

الملخص العربي

بحيرة أدكو أحد بحيرات مصر الثمالية و ثالثها من حيث المساحة و لها دور أ هام في

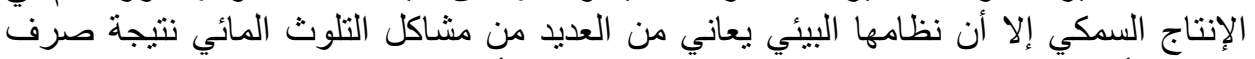

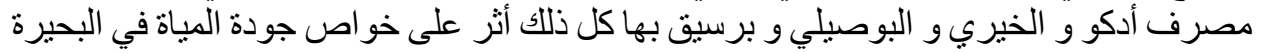

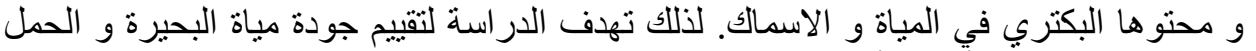
البيكتري في المياة و أنسجة أسماك البكاة الإني في البحيرة.

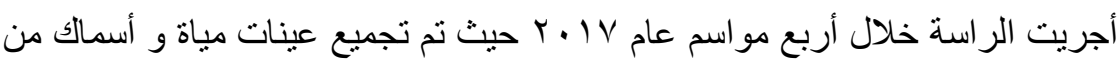
ستة مواقع في البحيرةو عمل تحليل درجة الحرارةـ الاس الهيدروجيني- الملوحهـ الأمونيا الكليةـ

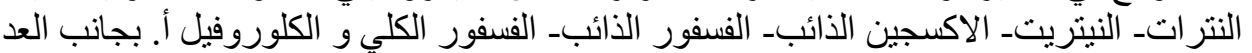

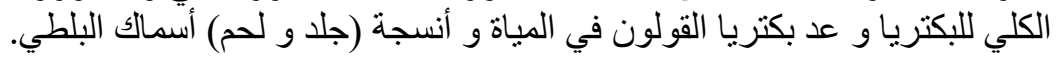

أوضحت نتائج الدر اسة أن قيم كلا من درجة الحر ارةو الأس الهيدروجيني و الأكسجين

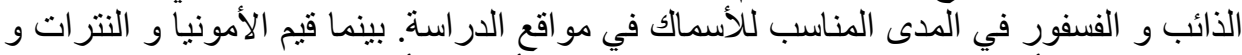

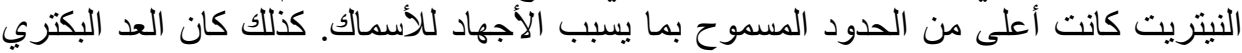

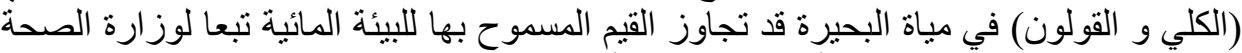

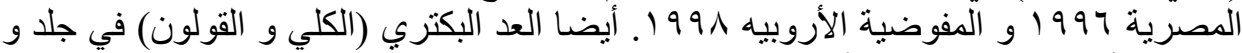

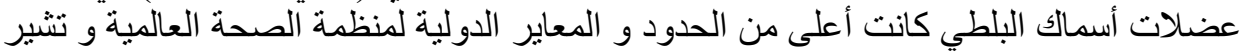

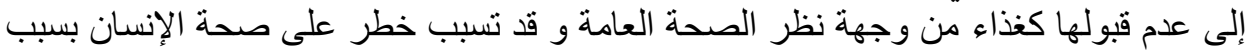
استهلاك البلطي كغذاء.

توصي الدراسة بضرورة معالجة الصرف النازحة للبحيرة للحد من الحمل البكتري

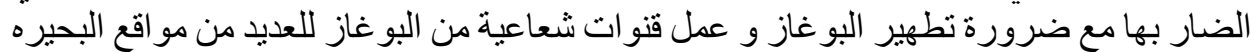

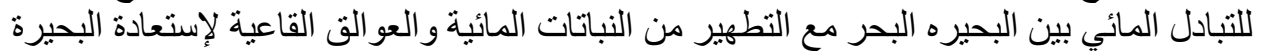
للتوازن البيئي. 